\title{
30. ROCK MAGNETIC PROPERTIES OF MAFIC ROCKS FROM THE MIDDLE VALLEY SEDIMENTED RIFT ${ }^{1}$
}

\author{
Koji Fukuma, ${ }^{2}$ Ulrike Körner, ${ }^{3}$ and Hirokuni Oda ${ }^{2}$
}

\begin{abstract}
Rock magnetic properties of mafic rocks from Sites 855 and 857 of Ocean Drilling Program Leg 139, in the Middle Valley of the northern Juan de Fuca Ridge, were evaluated as a source of marine magnetic anomalies. Magnetic mineralogy and magnetic properties of the basalt flows from Site 855 , located on the eastern boundary of the valley, are similar to those of typical young oceanic basalts. In contrast, the diabase sills at Site 857, situated well within the valley, are quite different from typical young oceanic basalts both in magnetic mineralogy and many magnetic properties. By thermomagnetic analyses and other magnetic methods, nearly pure magnetite was found to be a dominant magnetic carrier in the sills at Site 857. Saturation magnetization and susceptibility values, which are about two orders of magnitude lower than those of typical young oceanic basalts, suggest that the content of magnetic minerals in the Site 857 samples is much lower than in young oceanic basalts. As a result, natural remanent magnetization intensities are much lower than in young oceanic basalts. This low magnetization at Site 857 is consistent with the absence of expected marine magnetic anomalies over Middle Valley. We attribute the presence of magnetite and extremely low magnetization intensity to pervasive hydrothermal alteration of the rocks beneath a thick sediment blanket. Hydrothermal fluids leached iron from the original Fe-Ti oxides and greatly diminished the content of magnetic minerals. Our investigation suggests that hydrothermal alteration can cause subdued marine magnetic anomalies over sedimented rifts, as observed in several areas besides Middle Valley.
\end{abstract}

\section{INTRODUCTION}

The regional magnetic anomaly pattern over the northern Juan de Fuca Ridge indicates that Middle Valley is centered on the Brunhes normal polarity Chron (Raff and Mason, 1961). However, over Middle Valley the expected positive magnetic anomalies are absent and locally negative anomalies are observed instead (Davis and Lister, 1977; Currie and Davis, this volume). This aspect of the tectonic evolution of Middle Valley has been the subject of debate for many years (e.g., Barr and Chase, 1974). Middle Valley thus may be an exception to the Vine-Matthews model (Vine and Matthews, 1963). But there are other examples of Brunhes-age oceanic crust not accompanied by positive magnetic anomalies, including the Guaymas Basin of the Gulf of California (Larson et al., 1972), the Paul Revere Ridge and Winona Basin (Davis and Riddihough, 1982), and the Escanaba Trough on the southern Gorda Ridge (Raff and Mason, 1961).

In addition to the absence of positive magnetic anomalies, these areas are generally characterized by thick sediment covers (usually more than $500 \mathrm{~m}$ ) on young oceanic crust. A causal relationship between the thick sediment cover and the subdued magnetic anomaly was suggested previously (e.g., Larson et al., 1972). Moreover, several mechanisms have been proposed to explain how a thick sediment blanket could inhibit the production of magnetic anomalies (Levi and Riddihough, 1986): (1) elevated temperature above the Curie point expected beneath a thick sediment blanket would decrease the spontaneous magnetization of underlying rocks, and hence reduce or possibly eliminate the observed anomalies, (2) magmas crystallizing under sediment cover will cool more slowly to produce intrusive rocks that have larger grain sizes and correspondingly lower remanence intensities and stabilities than extrusive rocks of similar composition, and (3) pervasive hydrothermal alteration of oceanic crust at sedimented spreading centers would lead to the leaching of mag-

\footnotetext{
${ }^{1}$ Mottl, M.J., Davis, E.E., Fisher, A.T., and Slack, J.F. (Eds.), 1994. Proc. ODP, Sci. Results, 139: College Station, TX (Ocean Drilling Program).

${ }^{2}$ Department of Geology and Mineralogy, Faculty of Science, Kyoto University, Kyoto 606-01, Japan.

${ }^{3}$ Institut für Allgemeine und Angewandte Geophysik, Ludwig-Maximilians-Universität München, Theresienstrasse 41, D-8000 München 2, Germany.
}

netic minerals and hence reduce the magnetization of mafic rocks, consequently subduing the associated anomalies.

The rock magnetic study of mafic rocks recovered during Ocean Drilling Program (ODP) Leg 139 provides a unique opportunity to test the several hypothesized mechanisms for subduing marine magnetic anomalies over sedimented ridges. Some basalt samples, which are fresh or slightly altered, were collected from Site 855 at the eastern boundary of Middle Valley. Because these rocks are lithologically similar to typical young oceanic basalts, the magnetic properties of these samples are regarded as a reference to which other samples can be compared. Also we were able to obtain numerous vertically oriented samples from the mafic rocks at Site 857 , well within Middle Valley. The mafic rocks from Site 857 probably characterize those associated with the subdued marine magnetic anomalies over the Middle Valley. Although Site 857 is located only $6 \mathrm{~km}$ west of Site 855 , the lithology and alteration of the recovered mafic rocks are quite different from those at Site 855 . The Site 857 rocks are composed of primarily diabase sills intercalated with sediments and are intensely altered by hydrothermal fluids. A similar lithology was drilled beneath the Guaymas Basin in the Gulf of California (Curray and Moore, 1982), so these rocks are interpreted to be representative of materials formed at sedimented spreading centers. Our study shows that the intense hydrothermal alteration of igneous rocks beneath a thick sediment cover can lead to the suppression of associated marine magnetic anomalies.

\section{METHODS}

Remanence properties were measured both at the ODP shipboard laboratory and at the paleomagnetics laboratories of Kyoto University and Universität München. Magnetic remanence measurements were made on a MOLSPIN portable rock magnetometer on board, a Schonstedt spinner magnetometer at Kyoto University, and a Digico spinner and LETI cryogenic magnetometer at Universität München. Alternating field (AF) demagnetization was employed in a Schonstedt $\mathrm{AF}$ demagnetizer on board, in a custom-built demagnetizer with a three-axis tumbling device at Kyoto University, and in a 2G Enterprises demagnetizer at Universität München. Anhysteretic remanent magnetization (ARM) was induced in a peak alternating magnetic field of $140 \mathrm{mT}$ coupled with a coaxial direct bias field of $0.05 \mathrm{mT}$ in 
a $2 \mathrm{G}$ Enterprises demagnetizer at Kyoto University. Thermal demagnetization was carried out using a custom-built demagnetizer at Kyoto University that magnetically shielded to less than $5 \mathrm{nT}$. Low-field susceptibility was measured with a Bartington susceptibility meter in the low-frequency mode $(0.46 \mathrm{kHz})$.

Thermomagnetic measurements were done with a horizontal Curie balance by heating small rock fragments in Ar gas or in air, with the applied field of 0.40-0.55 T (Universität München) and 0.85 T (Kyoto University). Hysteresis loops were obtained using a Princeton vibrating sample magnetometer at the National Institute of Polar Research in Tokyo and a MOLSPIN vibrating sample magnetometer at Universität München.

\section{RESULTS}

\section{Site 855}

The hard-rock samples recovered from Site 855 are a variety of fresh to slightly altered extrusive basalts (Davis, Mottl, Fisher, et al., 1992). Two unoriented amples from Holes $855 \mathrm{~A}$ and $855 \mathrm{~B}$, from the foot wall of the normal fault beneath the less than $100 \mathrm{~m}$ of sediment, show irreversible thermomagnetic curves (Fig. 1A), which are interpreted to indicate the presence of titanomaghemite (Ozima and Larson, 1970). Originally crystallized titanomagnetite is converted to titanomaghemite through low-temperature oxidation. Titanomaghemite, as well as its precursor titanomagnetite, is a common magnetic mineral in young oceanic basalts (Irving, 1970; Johnson and Atwater, 1977). The hysteresis parameters of these samples are comparable to those of typical young oceanic basalts, as represented by the basalt samples from Deep Sea Drilling Project (DSDP)/ODP Hole 504B (Table 1) (Pariso and Johnson, 1991). The NRM intensities for the Site 855 samples are similar to or somewhat higher than those of normal oceanic basalt of the same age (Bleil and Petersen, 1983). The rock magnetic properties of basaltic rocks recovered from Site 855 are generally similar to those of typical young oceanic basalts.

\section{Site 857}

From Holes $857 \mathrm{C}$ and $857 \mathrm{D}$, we obtained about 100 vertically oriented samples of mafic rocks intercalated with sediment ranging from 470 to 936 meters below seafloor (mbsf) in depth. These samples were taken from a variety of sill units intercalated with sediments and vary in lithology from diabase to microgabbro. Most of the samples are highly altered by hydrothermal fluids to form epidote, chlorite, and pyrite as secondary minerals. The in-situ temperature is estimated to be about $300^{\circ} \mathrm{C}$ (Davis, Mottl, Fisher, et al., 1992; Langseth and Becker, this volume).

\section{Magnetic Mineralogy}

To identify the magnetic minerals of the diabase sills recovered from Holes $857 \mathrm{C}$ and $857 \mathrm{D}$, we conducted thermomagnetic analysis, acquisition of isothermal remanent magnetization (IRM), and progressive thermal demagnetization (PThD) of composite IRM (Lowrie, 1990). These magnetic measurements provide useful information about the magnetic mineralogy but do not reveal the origin of magnetic minerals. In addition to these magnetic methods, we examined the opaque minerals under the microscope to estimate the grain size and degree and type of alteration. We co..npared these results to the petrographic results obtained by Davis, Mottl, Fisher, et al. (1992).

For most sills at Site 857 , the thermomagnetic analyses showed predominantly hyperbolic curves during both heating and cooling cycles in Ar gas (Fig. 1B). This characteristic suggests that paramagnetic minerals dominate the strong-field magnetization and little "ferromagnetic" material is present. Nevertheless, an upward convex portion departed from the paramagnetic curve between $400^{\circ} \mathrm{C}$ and $580^{\circ} \mathrm{C}$ is due to a ferromagnetic component in the sample. A Curie temperature of about $580^{\circ} \mathrm{C}$ suggests the presence of nearly pure
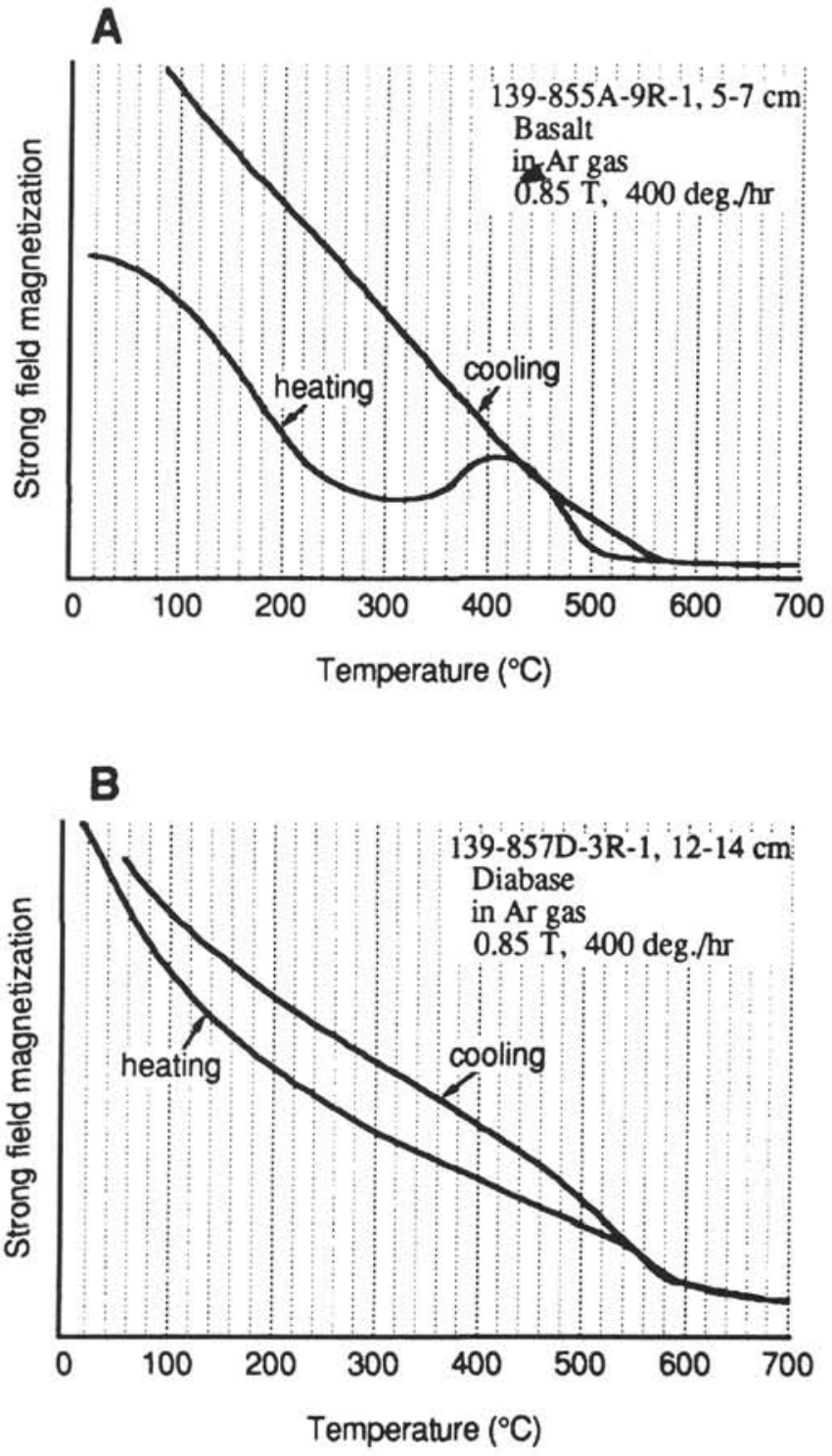

Figure 1. Representative thermomagnetic curves. A. Basalt flow at Site 855 heated in Ar gas. B. Diabase sill at Site 857 heated in Ar gas. C. Diabase sill with high content of magnetite at Site 857. D. Diabase sill at Site 857 heated in air. Same sample as Figure 1B.

magnetite. On a few samples reversible and upward convex curves were observed, which are indicative of abundant magnetite (Fig. 1C). As discussed below, samples displaying this type of curves contain a large amount of magnetite as shown by the high saturation magnetization and susceptibility values (Tables 1 and 2). For comparison, we performed thermomagnetic analyses in air for a sister sample measured in Ar gas (Fig. 1D). A magnetization hump ranging from $420^{\circ} \mathrm{C}$ to $560^{\circ} \mathrm{C}$ was observed in the heating run, along with a Curie point of $650^{\circ} \mathrm{C}$ detected in both runs. During the heating cycle some iron-bearing phases probably converted to the ferromagnetic phases, which make a hump because of its large strong field magnetization. The ferromagnetic phase further oxidizes to hematite above $470^{\circ} \mathrm{C}$ and the strong-field magnetization is reduced. Original magnetite, which is detected by thermomagnetic measurements in Ar gas, would also oxidize to hematite during heating in air. Pyrrhotite was not detected in our thermomagnetic analyses either in Ar gas or in air for any of the samples.

To estimate the originally contained ferromagnetic minerals only, IRM acquisition experiments were done on four selected samples. The 


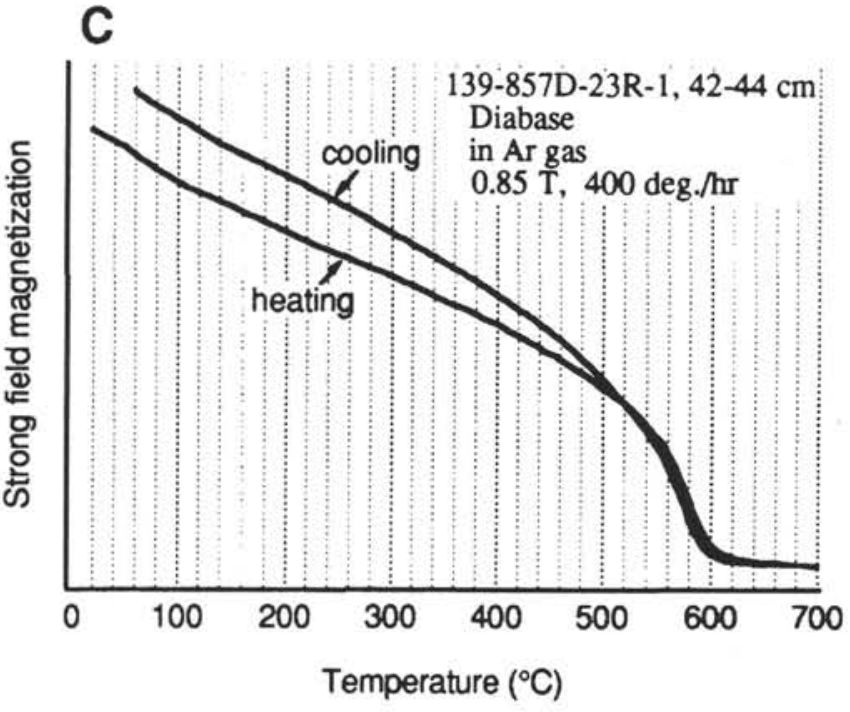

D

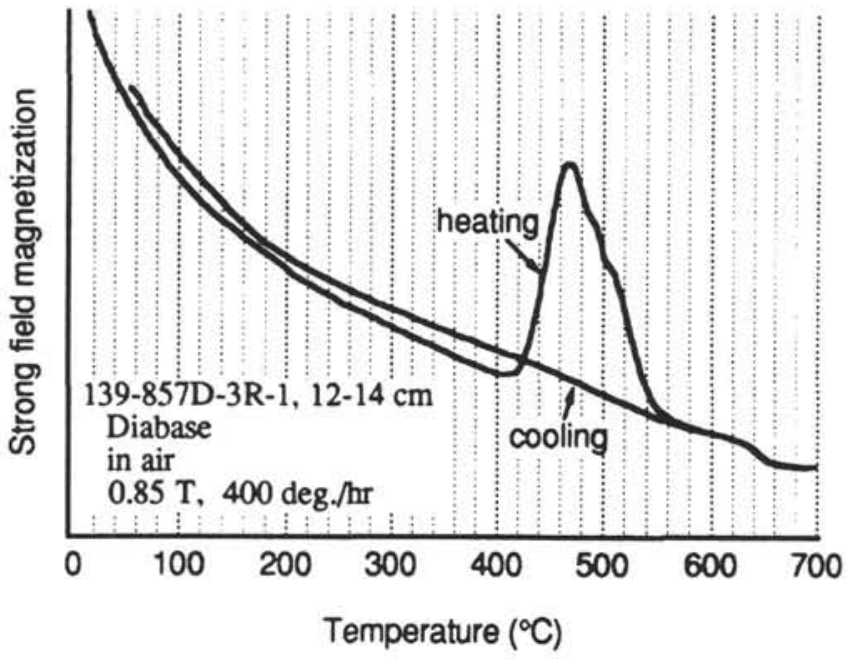

Figure 1 (continued).

paramagnetic component in thermomagnetic analysis largely masks the ferromagnetic phase and the chemical change of iron-bearing minerals is unavoidable during heating. As shown in Figure 2, the IRM of all these samples saturates in a magnetizing field less than $0.3 \mathrm{~T}$ and a higher coercivity mineral is absent. This indicates that principal magnetic carriers are ferrimagnetic minerals such as magnetite and that the content of pyrrhotite and hematite is insignificant in these samples.

In addition, we performed PThD of composite IRM on nine samples from Site 857 . Unlike thermomagnetic analyses or IRM acquisition, this method has the advantage of being able to evaluate only the ferromagnetic minerals, with different unblocking temperature and coercivity ranges, separated from paramagnetic minerals. Our particular aim to confirm the predominance of magnetite relative to pyrrhotil and other phases, as expected from the preceding results. The nine samples were tested and shared essentially the same characteristics as shown in Figure 3. The initial IRM intensity of the lowest coercivity component (less than $0.12 \mathrm{~T}$ ) is much higher than those of the other two higher coercivity components. The unblocking temperature spectrum of the lowest coercivity component is concentrated between $530^{\circ} \mathrm{C}$ and $590^{\circ} \mathrm{C}$. These characteristics indicate that the dominant magnetic carrier is nearly pure magnetite, consistent with the

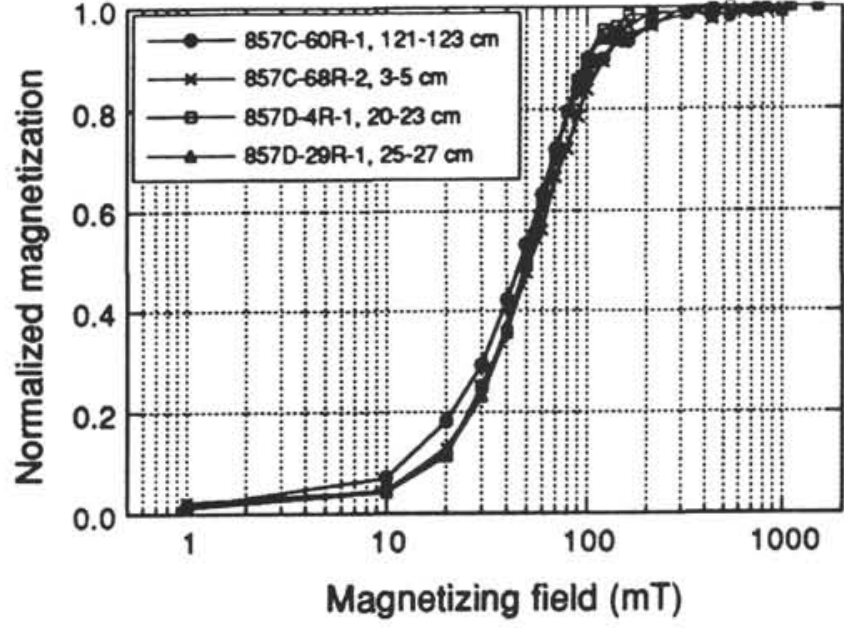

Figure 2. IRM acquisition curves for four selected samples. Intensity is normalized by the maximum values of each sample. Because the applied direct field is shown in logarithmic scale, intensity prior to acquisition is plotted at $1 \mathrm{mT}$.

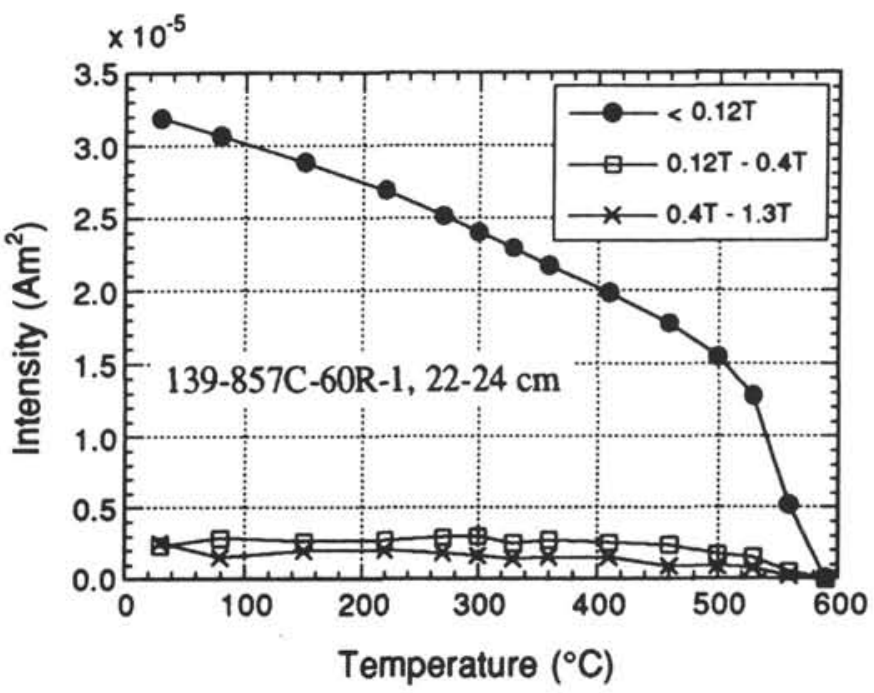

Figure 3. Progressive thermal demagnetization curves of mutually orthogonal three-component isothermal remanent magnetization.

thermomagnetic and IRM acquisition results. Pyrrhotite appears to make an insignificant contribution to remanence of the sills at Site 857.

Low-field susceptibility was measured between heating steps during PThD of IRM (Fig. 4) to assess the changes in the magnetic minerals during heating. For most samples, our data suggest that an initial mineral alters to phases with a higher susceptibility above $400^{\circ} \mathrm{C}$. This behavior corresponds to an increase in strong-field magnetization above $420^{\circ} \mathrm{C}$ (Fig. 1D). Although the increase in susceptibility above $400^{\circ} \mathrm{C}$ is evident for most samples, some samples show only small increases or even decreases. These few samples contain abundant magnetite compared with the other samples, as shown by the thermomagnetic curve dominated by ferromagnetic materials (Fig. 1C).

The opaque mineralogy of the sills at Site 857 is summarized below from the petrographic work on board (Davis, Mottl, Fisher, et al., 1992) and our observations. Sulfides, dominantly pyrite, are the most abundant opaque mineral and often occur as interstitial aggregates up to $0.5 \mathrm{~cm}$ across as a secondary phase in the rock matrix (PI. 1, Fig. 1). Primary oxide minerals have been extensively hydrother- 
Table 1. Hysteresis properties from Sites 855 and 857.

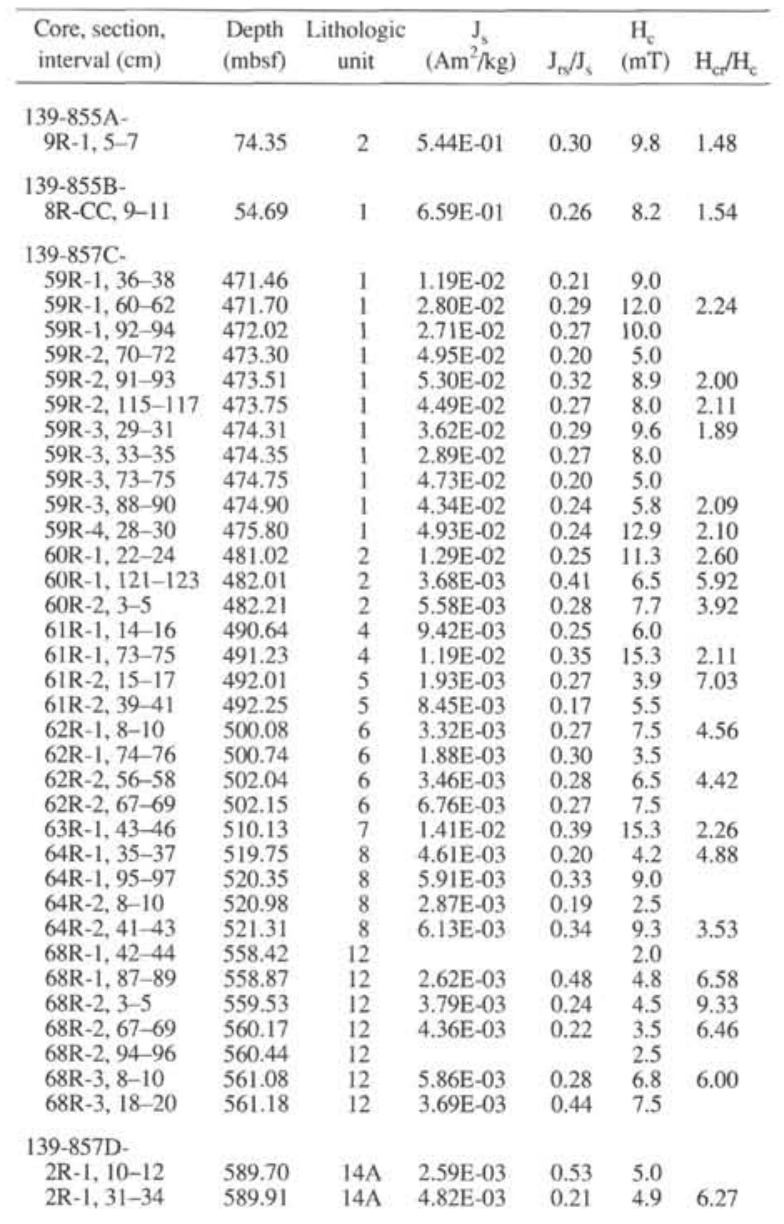

mally altered in the manner first described by Ade-Hall et al. (1971) as "granulation," where Fe-Ti oxide phenocrysts are almost ghosts. They seem opaque under transmitted-light microscope (Pl. 1, Fig. 2) but are not reflective under a reflected-light microscope (Pl. 1, Fig. 3). Small reflective patches measuring less than $10 \mu \mathrm{m}$, presumably magnetite, are distributed in the altered Fe-Ti oxide. The other part of the alteration product is a titanium-bearing phase such as sphene or anatase. It appears that iron contained in primary $\mathrm{Fe}-\mathrm{Ti}$ oxide remained in the secondary magnetite or was leached from the spinel lattice. Small Fe-Ti oxides are present as interstitial grains or crystallites within mesostasis (Pl. 1, Fig. 4). Because of its small grain size, we cannot determine whether this phase is titanomagnetite or ilmenite, or the degree of alteration it has experienced.

We summarize the results of the magnetic analyses and microscopic observations on the diabase sills at Site 857 as follows. Nearly pure magnetite is the principal magnetic mineral and is of secondary origin. Hydrothermal alteration of primary $\mathrm{Fe}-\mathrm{Ti}$ oxides led to the formation of secondary magnetite. Although some of the leached iron from the primary $\mathrm{Fe}-\mathrm{Ti}$ oxides remains in magnetite, most of the leached iron was removed by hydrothermal fluids or precipitated as secondary iron sulfide. Pyrite, confirmed by microscope observations, may produce ferromagnetic minerals during laboratory heating (Channel and Hawthorne, 1990). Pyrrhotite coexisting with pyrite was observed by petrographic work on board (Davis, Mottl, Fisher, et al., 1992). We also confirmed the presence of magnetic pyrrhotite by using ferrofluids under the microscope, although no magnetic method detected significant amounts of pyrrhotite. The pyrrhotite

\begin{tabular}{|c|c|c|c|c|c|c|}
\hline $\begin{array}{l}\text { Core, section, } \\
\text { interval }(\mathrm{cm})\end{array}$ & $\begin{array}{l}\text { Depth } \\
\text { (mbsf) }\end{array}$ & $\begin{array}{c}\text { Lithologic } \\
\text { unit }\end{array}$ & $\left(\mathrm{Am}^{2} / \mathrm{kg}\right)$ & $\mathrm{J}_{\mathrm{rs}} / \mathrm{J}_{\mathrm{s}}$ & $\begin{array}{l}\mathrm{H}_{\mathrm{c}} \\
(\mathrm{mT})\end{array}$ & $\mathrm{H}_{c r} / \mathrm{H}_{\mathrm{c}}$ \\
\hline $3 R-1,12-14$ & 599.42 & $14 B$ & $1.12 \mathrm{E}-02$ & 0.19 & 8.6 & 2.61 \\
\hline $3 \mathrm{R}-1,38-41$ & 599.68 & $14 B$ & $8.40 \mathrm{E}-04$ & 0.85 & 4.0 & \\
\hline $3 \mathrm{R}-1,93-96$ & 600.23 & $14 B$ & $3.95 \mathrm{E}-03$ & 0.31 & 5.0 & \\
\hline $3 R-2,14-16$ & 600.91 & $14 B$ & $4.37 \mathrm{E}-03$ & 0.22 & 5.6 & \\
\hline $3 R-2,57-59$ & 601.34 & $14 B$ & $3.42 \mathrm{E}-03$ & 0.49 & 8.5 & \\
\hline $4 \mathrm{R}-1,20-23$ & 609.10 & 15 & $7.05 \mathrm{E}-03$ & 0.23 & 7.0 & 6.71 \\
\hline $4 \mathrm{R}-1,75-78$ & 609.65 & 15 & $5.47 \mathrm{E}-03$ & 0.26 & 6.3 & 3.89 \\
\hline $4 \mathrm{R}-2,24-27$ & 610.64 & 15 & $2.88 \mathrm{E}-03$ & & & \\
\hline $8 \mathrm{R}-1,2-4$ & 647.32 & $16 \mathrm{~B}$ & $3.75 \mathrm{E}-03$ & 0.27 & 5.2 & 2.48 \\
\hline $9 \mathrm{R}-1,19-21$ & 657.09 & $16 \mathrm{C}$ & $2.04 \mathrm{E}-02$ & 0.49 & 20.5 & \\
\hline $9 R-1,66-68$ & 657.56 & $16 \mathrm{C}$ & $9.44 \mathrm{E}-03$ & 0.31 & 8.1 & 4.48 \\
\hline $12 R-2,40-43$ & 687.70 & $17 \mathrm{~A}$ & $1.01 \mathrm{E}-02$ & 0.38 & 13.5 & 3.34 \\
\hline $17 \mathrm{R}-3,65-67$ & 737.49 & 19 & $1.59 \mathrm{E}-03$ & 0.43 & 3.5 & \\
\hline $18 \mathrm{R}-1,9-11$ & 743.69 & 19 & $7.75 \mathrm{E}-03$ & 0.21 & 6.4 & 6.27 \\
\hline $18 \mathrm{R}-1,24-26$ & 743.84 & 19 & $3.79 \mathrm{E}-03$ & 0.35 & 5.5 & \\
\hline $18 \mathrm{R}-1,110-112$ & 744.70 & 19 & $3.04 \mathrm{E}-03$ & 0.39 & 5.5 & \\
\hline $18 \mathrm{R}-2,56-58$ & 745.58 & 19 & $4.67 \mathrm{E}-03$ & 0.21 & 5.5 & \\
\hline $20 \mathrm{R}-1,52-54$ & 763.02 & 19 & $7.27 \mathrm{E}-03$ & 0.17 & 5.0 & 4.46 \\
\hline $20 R-1,69-71$ & 763.19 & 19 & $1.28 \mathrm{E}-02$ & 0.10 & 3.5 & \\
\hline $21 \mathrm{R}-1,52-54$ & 772.72 & $20 \mathrm{~A}$ & $4.77 \mathrm{E}-03$ & 0.53 & 10.5 & \\
\hline $21 \mathrm{R}-1,94-96$ & 773.14 & $20 \mathrm{~A}$ & $1.29 \mathrm{E}-02$ & 0.31 & 12.8 & 3.05 \\
\hline $22 \mathrm{R}-1,66-68$ & 782.46 & 20D & $3.36 \mathrm{E}-03$ & 0.25 & 6.4 & 5.17 \\
\hline $23 \mathrm{R}-1,42-44$ & 791.92 & $20 \mathrm{D}$ & $1.74 \mathrm{E}-01$ & 0.18 & 12.2 & 1.89 \\
\hline $23 \mathrm{R}-1,61-63$ & 792.11 & $20 \mathrm{D}$ & $2.68 \mathrm{E}-02$ & 0.23 & 9.5 & \\
\hline $24 \mathrm{R}-2,50-52$ & 803.20 & 21 & $2.81 \mathrm{E}-02$ & 0.16 & 9.1 & 3.26 \\
\hline $24 \mathrm{R}-2,71-73$ & 803.41 & 21 & $1.18 \mathrm{E}-02$ & 0.27 & 9.0 & \\
\hline $24 \mathrm{R}-3,10-12$ & 804.19 & 21 & $1.54 \mathrm{E}-02$ & 0.14 & 7.0 & 3.10 \\
\hline $25 \mathrm{R}-1,20-22$ & 811.00 & 21 & $1.11 \mathrm{E}+00$ & 0.11 & 7.0 & \\
\hline $25 \mathrm{R}-1,48-50$ & 811.28 & 21 & 8.97E-01 & 0.17 & 9.2 & 1.60 \\
\hline $25 \mathrm{R}-1,88-90$ & 811.68 & 21 & $1.10 \mathrm{E}+00$ & 0.10 & 6.5 & \\
\hline $26 \mathrm{R}-1,3-5$ & 820.33 & 21 & $8.27 \mathrm{E}-03$ & 0.19 & 7.8 & 4.18 \\
\hline $26 \mathrm{R}-1.54-56$ & 820.84 & 21 & 7.35E-03 & 0.20 & 6.5 & \\
\hline $27 \mathrm{R}-1,83-85$ & 830.43 & 22 & $1.34 \mathrm{E}-02$ & 0.31 & 10.5 & \\
\hline $29 \mathrm{R}-1,55-57$ & 848.95 & $23 \mathrm{~A}$ & $5.28 \mathrm{E}-03$ & 0.27 & 7.1 & 5.01 \\
\hline $29 \mathrm{R}-1,127-129$ & 849.67 & $23 \mathrm{~A}$ & $1.07 \mathrm{E}-02$ & 0.27 & 10.0 & \\
\hline $29 \mathrm{R}-2,25-27$ & 850.15 & $23 \mathrm{~A}$ & $8.90 \mathrm{E}-03$ & 0.32 & 9.0 & \\
\hline $33 \mathrm{R}-1,65-67$ & 888.45 & 24 & $1.31 \mathrm{E}-03$ & 0.15 & 7.0 & 6.57 \\
\hline $35 \mathrm{R}-1,62-64$ & 907.82 & $25 \mathrm{~B}$ & $8.61 \mathrm{E}-03$ & 0.31 & 7.5 & \\
\hline $35 \mathrm{R}-1,98-100$ & 908.18 & $25 B$ & $1.72 \mathrm{E}-02$ & 0.24 & 8.3 & 4.00 \\
\hline $36 \mathrm{R}-1,17-19$ & 917.07 & $25 \mathrm{C}$ & $8.10 \mathrm{E}-03$ & 0.33 & 9.0 & \\
\hline $36 \mathrm{R}-1,56-58$ & 917.46 & $25 \mathrm{C}$ & $4.65 \mathrm{E}-03$ & 0.31 & 5.7 & 5.53 \\
\hline $36 \mathrm{R}-1,91-93$ & 917.81 & $25 \mathrm{C}$ & $9.29 \mathrm{E}-03$ & 0.31 & 9.5 & \\
\hline
\end{tabular}

Note: $\mathrm{J}_{\mathrm{s}}=$ saturation magnetization, $\mathrm{J}_{\mathrm{rs}}=$ saturation remanence, $\mathrm{H}_{\mathrm{c}}=$ coercivity, and $\mathrm{H}_{\mathrm{cr}}=$ coercivity of remanence.

observed under the microscope does not appear to contribute significantly to remanence.

\section{Hysteresis Properties}

Hysteresis properties are used to estimate the magnetic mineral content, stability, and indirectly the grain size. The basic four parameters are presented in Table 1 and are plotted with depth in Figure 5. Averages of these parameters are presented in Table 3 in comparison with those from three lithologic sections of DSDP/ODP Hole 504B, which are presumed representative of young oceanic crust.

In principle, the value of saturation magnetization, $\mathrm{J}_{\mathrm{s}}$, depends only on the composition and concentration of "ferromagnetic" minerals in rocks. As previously indicated, the magnetic mineralogy of the sills at Site 857 is uniform with depth and predominated by nearly pure magnetite. The saturation magnetization values of samples from Site 857 are, therefore, supposed to reflect the magnetite content of these rocks. Except for two intervals at about 470 and $800 \mathrm{mbsf}, \mathrm{J}_{\mathrm{s}}$ values are uniform and extremely low throughout the recovered core from Site 857. These low and uniform $\mathrm{J}_{\mathrm{s}}$ values are about two orders of magnitude lower than the average values from the extrusive basalts at Hole 504B. The overall mean value of $\mathrm{J}_{\mathrm{s}}$ from Site 857, which includes the two intervals with anomalously high $\mathrm{J}_{\mathrm{s}}$ values, is only $0.055 \mathrm{Am}^{2} / \mathrm{kg}$. This value is about an order of magnitude lower than the average value of the basalt section at Hole 504B. In addition, the average $\mathrm{J}_{5}$ value from Site 857 is lower even than that of the transition zone from Hole 504B, which experienced greenschist facies alteration. 


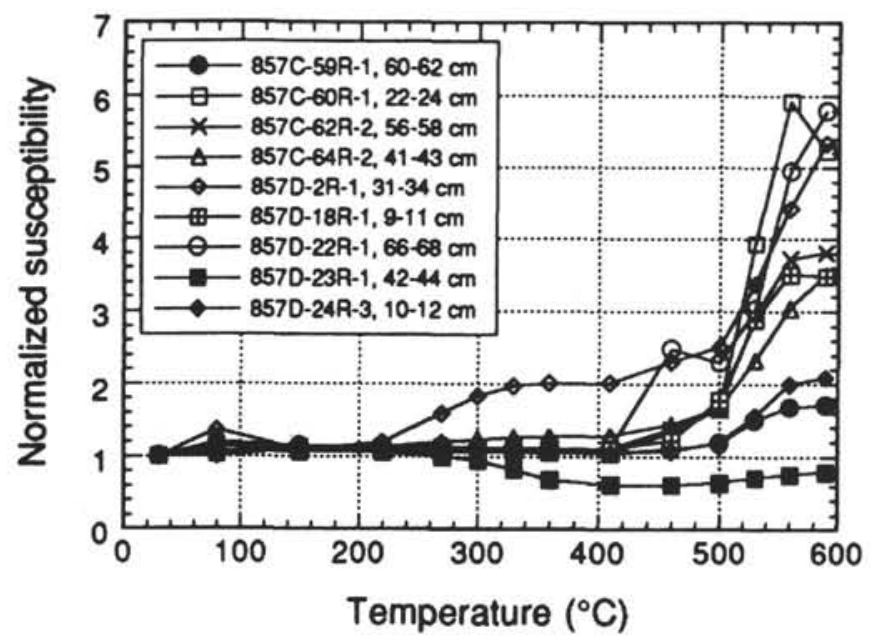

Figure 4. Normalized low-field susceptibility variations during progressive thermal demagnetization on nine samples from Site 857. Samples plotted with open symbols show pronounced increases above $400^{\circ} \mathrm{C}$; samples plotted with solid symbols show little increase.

The ratio of saturation remanence to saturation magnetization, $\mathrm{J}_{\mathrm{rs}} / \mathrm{J}_{\mathrm{s}}$, has been used as an estimate of the magnetic domain structure or magnetic grain size (Day et al., 1977). An assemblage of singledomain grains has a $\mathrm{J}_{\mathrm{rs}} / \mathrm{J}_{\mathrm{s}}$ value larger than 0.5 . Larger multidomain grains have $\mathrm{J}_{\mathrm{rs}} / \mathrm{J}_{\mathrm{s}}$ values much less than 0.1 . Between single-domain and multidomain sizes $\mathrm{J}_{\mathrm{rs}} / \mathrm{J}_{\mathrm{s}}$ values vary gradually. Grain size is also generally related to the stability of magnetization for geologically long periods. Single-domain grains are the most stable. As grain size increases, the magnetic grains become less stable. Therefore we can also estimate the magnetic stability from $\mathrm{J}_{\mathrm{rs}} / \mathrm{J}_{\mathrm{s}}$ values. The average $\mathrm{J}_{\mathrm{r}} / \mathrm{J}_{\mathrm{s}}$ value at Site 857 of 0.28 is similar to or slightly higher than the average values of the basalts, the transition zone, and the sheeted dikes of Hole 504B. Magnetite in the sills at Site 857 is probably in pseudo-single-domain (PSD) size like the magnetic materials of Hole 504B, and the magnetic stability is presumably high. Plotted with depth, $\mathrm{J}_{\mathrm{s}} / \mathrm{J}_{\mathrm{s}}$ values are fairly scattered, with no recognizable trend. An interval near 800 mbsf with high $\mathrm{J}_{\mathrm{s}}$ values is characterized by small $\mathrm{J}_{\mathrm{rs}} / \mathrm{J}_{\mathrm{s}}$ values, indicating that the effective grain size of magnetite in this interval is larger than that in the other sills.

Magnetic coercivity, $\mathrm{H}_{c}$, is used to estimate the intrinsic stability of magnetization. This parameter is generally correlated with $\mathrm{J}_{\mathrm{rs}} / \mathrm{J}_{\mathrm{s}}$ and magnetic grain size. That means smaller magnetic grains (higher $\mathrm{J}_{\mathrm{rs}} / \mathrm{J}_{\mathrm{s}}$ ) are associated with higher coercivity. The average $\mathrm{H}_{\mathrm{c}}$ value at Site 857 is $7.55 \mathrm{mT}$, which is similar to the value of the basalts at Hole 504B but lower than those of the transition zone and the sheeted dike section. Similar to the $\mathrm{J}_{\mathrm{rs}} / \mathrm{J}_{\mathrm{s}}$ values, the $\mathrm{H}_{\mathrm{c}}$ values do not indicate a significant trend with depth and are more scattered overall than the $\mathrm{J}_{\mathrm{rs}} / \mathrm{J}_{\mathrm{s}}$ values. Although low $\mathrm{H}_{\mathrm{c}}$ values at about $800 \mathrm{mbsf}$ are expected from the variation of $\mathrm{J}_{\mathrm{rs}} / \mathrm{J}_{\mathrm{s}}$ with depth, these low values are not observed in the variation of $\mathrm{H}_{\mathrm{c}}$.

The ratio of coercivity of remanence to magnetic coercivity, $\mathrm{H}_{\mathrm{cr}} / \mathrm{H}_{\mathrm{c}}$, is another measure of magnetic stability. $\mathrm{H}_{\mathrm{cr}} / \mathrm{H}_{\mathrm{c}}$ is inversely correlated with $\mathrm{J}_{\mathrm{rs}} / \mathrm{J}_{\mathrm{s}}$ and gradually increases with increasing grain size (Day et al., 1977). For Site $857, \mathrm{H}_{\mathrm{cr}} / \mathrm{H}_{\mathrm{c}}$ values are scattered with depth. Neither positive or negative correlation is observed between $\mathrm{H}_{\mathrm{cr}} / \mathrm{H}_{\mathrm{c}}$ and $\mathrm{J}_{\mathrm{rs}} / \mathrm{J}_{\mathrm{s}}$ or $\mathrm{H}_{\mathrm{c}} . \mathrm{H}_{\mathrm{cr}} / \mathrm{H}_{\mathrm{c}}$ might not be definitive in determining
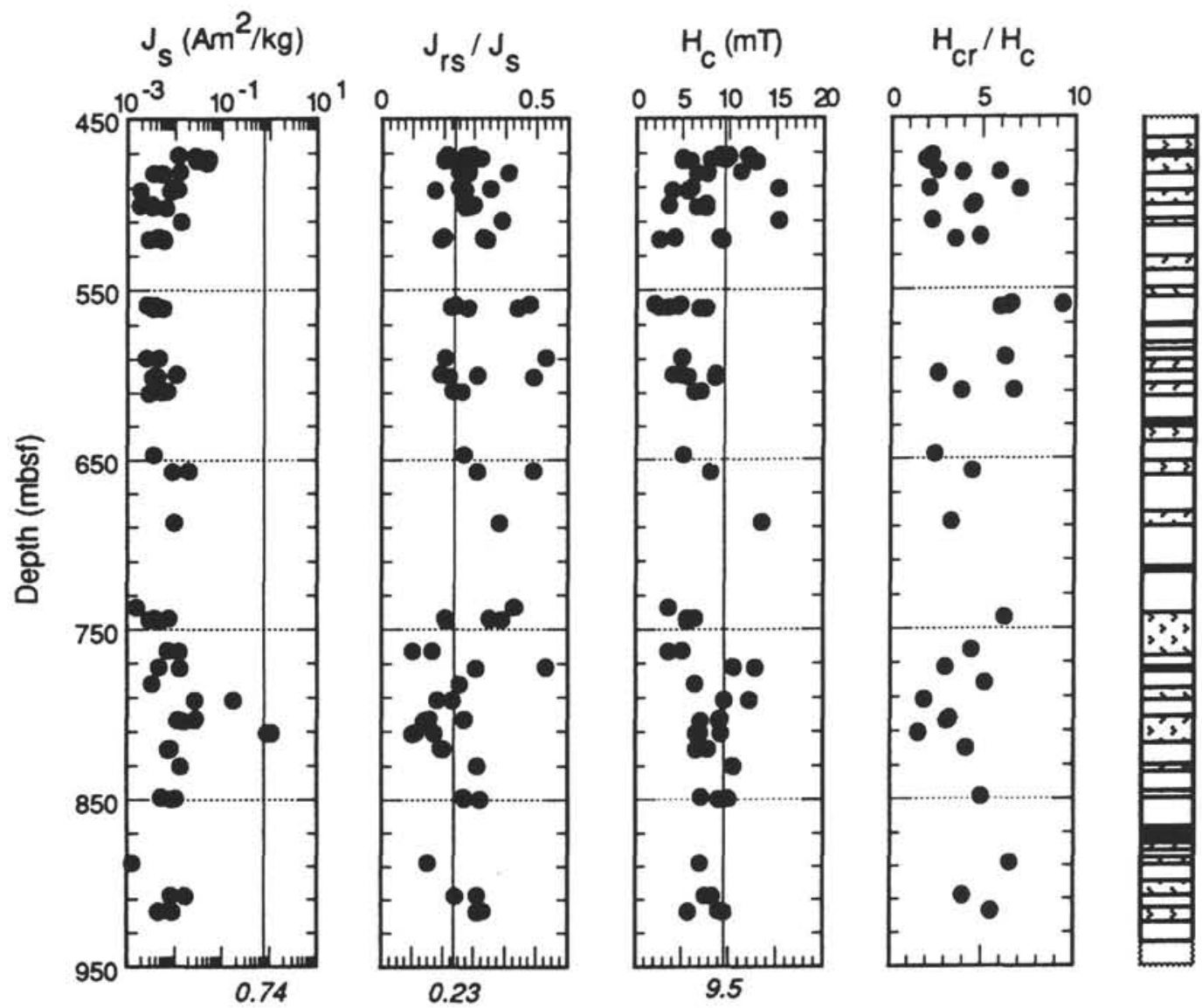

Figure 5. Depth variation of hysteresis properties at Site 857. Vertical lines represent the average values from Hole 504B basalts (Pariso and Johnson, 1991). Lithology is shown at the right of this figure. 
Table 2. Remanence properties from Sites 855 and 857.

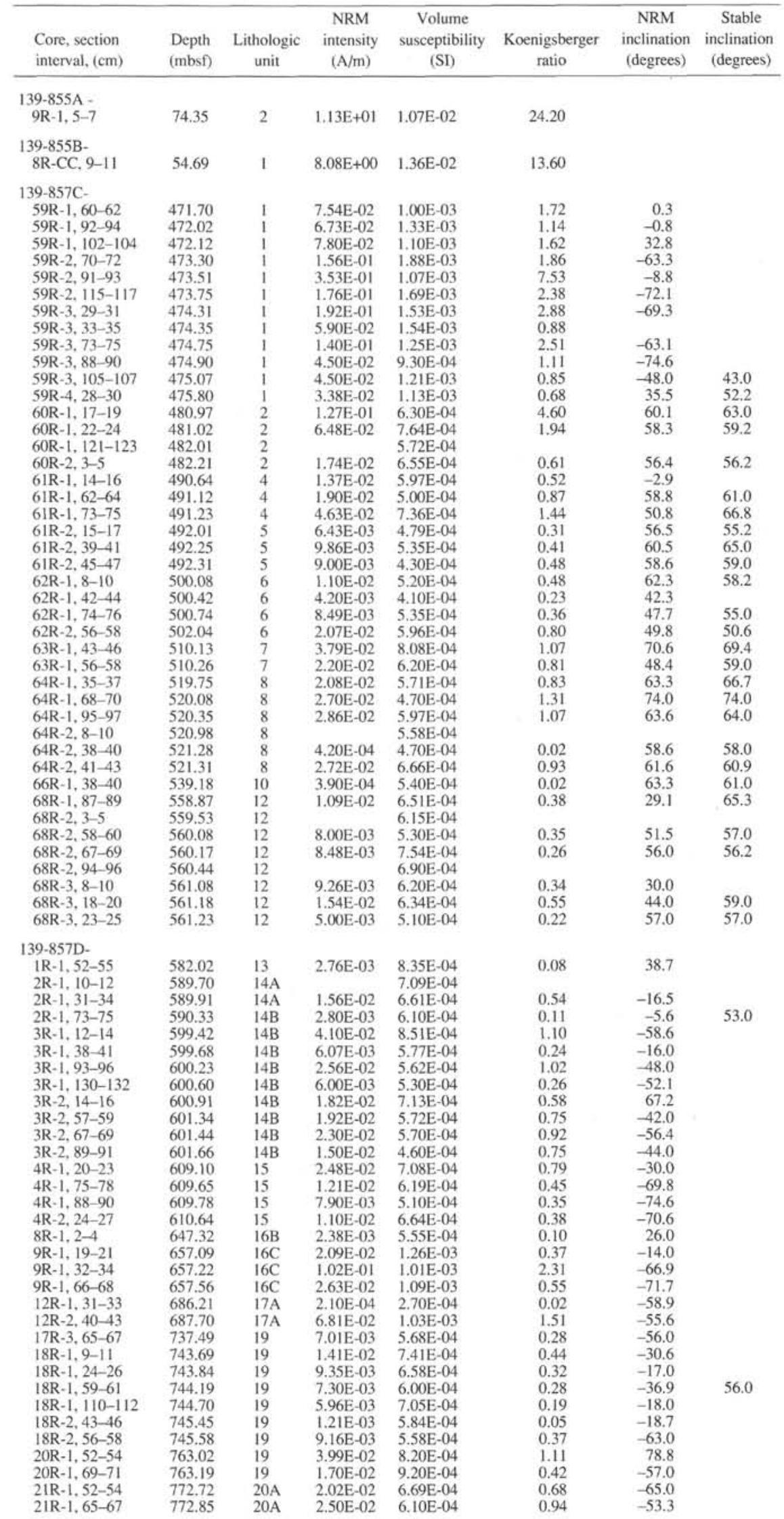


Table 2 (continued).

\begin{tabular}{|c|c|c|c|c|c|c|c|}
\hline $\begin{array}{l}\text { Core, section } \\
\text { interval, }(\mathrm{cm})\end{array}$ & $\begin{array}{l}\text { Depth } \\
\text { (mbsf) }\end{array}$ & $\begin{array}{l}\text { Lithologic } \\
\text { unit }\end{array}$ & $\begin{array}{c}\text { NRM } \\
\text { intensity } \\
(\mathrm{A} / \mathrm{m})\end{array}$ & $\begin{array}{c}\text { Volume } \\
\text { susceptibility } \\
\text { (SI) }\end{array}$ & $\begin{array}{l}\text { Koenigsberger } \\
\text { ratio }\end{array}$ & $\begin{array}{c}\text { NRM } \\
\text { inclination } \\
\text { (degrees) }\end{array}$ & $\begin{array}{c}\text { Stable } \\
\text { inclination } \\
\text { (degrees) }\end{array}$ \\
\hline $21 \mathrm{R}-1,94-96$ & 773.14 & $20 \mathrm{~A}$ & $2.78 \mathrm{E}-02$ & $6.33 \mathrm{E}-04$ & 1.00 & -13.8 & \\
\hline $22 \mathrm{R}-1,66-68$ & 782.46 & $20 \mathrm{D}$ & $2.14 \mathrm{E}-02$ & $5.51 \mathrm{E}-04$ & 0.89 & -82.9 & \\
\hline $22 \mathrm{R}-1,89-91$ & 782.69 & $20 \mathrm{D}$ & $2.70 \mathrm{E}-02$ & $6.70 \mathrm{E}-04$ & 0.92 & -65.5 & \\
\hline $23 \mathrm{R}-1,42-44$ & 791.92 & $20 \mathrm{D}$ & $1.21 \mathrm{E}+00$ & $7.63 \mathrm{E}-03$ & 3.62 & -82.9 & 57.0 \\
\hline $23 \mathrm{R}-1,61-63$ & 792.11 & $20 \mathrm{D}$ & $7.29 \mathrm{E}-02$ & $1.32 \mathrm{E}-03$ & 1.24 & -73.0 & \\
\hline $24 R-2,32-34$ & 803.02 & 21 & $4.00 \mathrm{E}-02$ & $7.10 \mathrm{E}-04$ & 1.29 & -81.0 & \\
\hline $24 \mathrm{R}-2,50-52$ & 803.20 & 21 & $5.74 \mathrm{E}-02$ & $1.17 \mathrm{E}-03$ & 1.12 & -83.8 & \\
\hline $24 \mathrm{R}-2,71-73$ & 803.41 & 21 & $4.95 \mathrm{E}-02$ & $9.09 \mathrm{E}-04$ & 1.22 & -73.0 & \\
\hline $24 \mathrm{R}-3,10-12$ & 804.19 & 21 & $3.60 \mathrm{E}-02$ & $8.64 \mathrm{E}-04$ & 0.95 & -65.5 & \\
\hline $25 \mathrm{R}-1,20-22$ & 811.00 & 21 & $4.87 \mathrm{E}-01$ & $3.13 \mathrm{E}-02$ & 0.35 & 9.0 & \\
\hline $25 \mathrm{R}-1,48-50$ & 811.28 & 21 & $5.83 \mathrm{E}+00$ & $2.09 \mathrm{E}-02$ & 6.36 & -74.1 & \\
\hline $25 \mathrm{R}-1,88-90$ & 811.68 & 21 & $2.03 \mathrm{E}-03$ & $2.82 \mathrm{E}-02$ & 0.00 & -53.0 & \\
\hline $26 \mathrm{R}-1,3-5$ & 820.33 & 21 & $1.53 \mathrm{E}-02$ & $5.46 \mathrm{E}-04$ & 0.64 & 60.1 & \\
\hline $26 \mathrm{R}-1,10-12$ & 820.40 & 21 & $2.40 \mathrm{E}-02$ & 5.50E-04 & 1.00 & 66.8 & \\
\hline $26 \mathrm{R}-1,54-56$ & 820.84 & 21 & $1.98 \mathrm{E}-02$ & $5.43 \mathrm{E}-04$ & 0.82 & -49.0 & \\
\hline $27 \mathrm{R}-1,83-85$ & 830.43 & 22 & $6.77 \mathrm{E}-02$ & $1.01 \mathrm{E}-03$ & 1.50 & -29.0 & \\
\hline $29 \mathrm{R}-1,55-57$ & 848.95 & $23 \mathrm{~A}$ & $3.19 \mathrm{E}-02$ & 7. $40 \mathrm{E}-04$ & 0.99 & -53.4 & \\
\hline $29 \mathrm{R}-1,127-129$ & 849.67 & $23 \mathrm{~A}$ & $4.38 \mathrm{E}-02$ & $7.98 \mathrm{E}-04$ & 1.23 & -69.0 & \\
\hline $29 \mathrm{R}-2,25-27$ & 850.15 & $23 \mathrm{~A}$ & $5.19 \mathrm{E}-02$ & $9.79 \mathrm{E}-04$ & 1.19 & -65.0 & \\
\hline $33 \mathrm{R}-1,65-67$ & 888.45 & 24 & $2.45 \mathrm{E}-02$ & $8.07 \mathrm{E}-04$ & 0.68 & -20.0 & \\
\hline $35 \mathrm{R}-1,62-64$ & 907.82 & $25 \mathrm{~B}$ & $2.31 \mathrm{E}-02$ & $1.02 \mathrm{E}-03$ & 0.51 & -33.0 & \\
\hline $35 \mathrm{R}-1,70-72$ & 907.90 & $25 \mathrm{~B}$ & $4.60 \mathrm{E}-02$ & $9.50 \mathrm{E}-04$ & 1.11 & -56.5 & \\
\hline $35 \mathrm{R}-1,98-100$ & 908.18 & $25 \mathrm{~B}$ & $5.05 \mathrm{E}-02$ & $1.09 \mathrm{E}-03$ & 1.06 & -49.9 & \\
\hline $36 \mathrm{R}-1,17-19$ & 917.07 & $25 \mathrm{~B}$ & $2.63 \mathrm{E}-02$ & $9.75 \mathrm{E}-04$ & 0.60 & -58.0 & \\
\hline $36 \mathrm{R}-1,56-58$ & 917.46 & $25 \mathrm{C}$ & $1.67 \mathrm{E}-02$ & $9.91 \mathrm{E}-04$ & 0.39 & -62.0 & \\
\hline $36 \mathrm{R}-1,91-93$ & 917.81 & $25 \mathrm{C}$ & $5.86 \mathrm{E}-02$ & $8.89 \mathrm{E}-04$ & 1.48 & -69.0 & \\
\hline
\end{tabular}

Table 3. Average magnetic properties from Site 857 and Hole 504B.

\begin{tabular}{|c|c|c|c|c|c|c|}
\hline & $\underset{\left(\mathrm{Am}^{2} / \mathrm{kg}\right)}{\mathrm{J}_{\mathrm{s}}}$ & $\mathrm{J}_{\mathrm{rs}} / \mathrm{J}_{\mathrm{s}}$ & $\begin{array}{l}\mathrm{H}_{\mathrm{c}} \\
(\mathrm{mT})\end{array}$ & $\begin{array}{c}\text { NRM } \\
\text { intensity } \\
(\mathrm{A} / \mathrm{m})\end{array}$ & $\begin{array}{c}\text { Volume } \\
\text { susceptibility } \\
\text { (SI) }\end{array}$ & $\begin{array}{c}\text { Koenigsberger } \\
\text { ratio }\end{array}$ \\
\hline Site 857 & 0.055 & 0.28 & 7.55 & 0.11 & 0.0016 & 1 \\
\hline $\begin{array}{l}\text { Hole 504B } \\
\text { Basalt } \\
\text { Transition zone } \\
\text { Sheeted dike }\end{array}$ & $\begin{array}{l}0.74 \\
0.2 \\
1\end{array}$ & $\begin{array}{l}0.23 \\
0.26 \\
0.24\end{array}$ & $\begin{array}{r}9.5 \\
14.4 \\
18.4\end{array}$ & $\begin{array}{l}5.2 \\
0.35 \\
1.6\end{array}$ & $\begin{array}{l}0.027 \\
0.004 \\
0.018\end{array}$ & $\begin{array}{r}13 \\
4 \\
5\end{array}$ \\
\hline
\end{tabular}

Note: Hole 504B data after Pariso and Johnson (1991).

magnetic grain size (Dunlop, 1983). This problem is discussed in detail in the following.

Magnetic hysteresis data indicate a very low content of magnetite in the diabase sills of Site 857 in comparison with young oceanic basalts, as is seen in $J_{s}$ values, which are lower by two orders of magnitude. Magnetic grain size and hence magnetic stability do not significantly differ from those of young oceanic basalts. The three hysteresis parameters related to magnetic stability, $\mathrm{J}_{\mathrm{rs}} / \mathrm{J}_{\mathrm{s}}, \mathrm{H}_{\mathrm{c}}$, and $\mathrm{H}_{\mathrm{cr}} / \mathrm{H}_{\mathrm{c}}$, show discordant variations within the recovered section of Site 857 . We plotted $\mathrm{J}_{\mathrm{rs}} / \mathrm{J}_{\mathrm{s}} \mathrm{vs} . \mathrm{H}_{\mathrm{cc}} / \mathrm{H}_{\mathrm{c}}$ for the sills of Site 857 (Fig. 6). The inverse relationship between $\mathrm{J}_{\mathrm{rs}} / \mathrm{J}_{\mathrm{s}}$ and $\mathrm{H}_{\mathrm{cr}} / \mathrm{H}_{\mathrm{c}}$, which is intrinsic to grain-size variations of magnetic minerals (Day et al., 1977), does not hold for the samples from Site 857. Although $\mathrm{J}_{\mathrm{rs}} / \mathrm{J}_{5}$ values are in the range of the PSD field defined by Day et al. (1977), $\mathrm{H}_{\mathrm{cr}} / \mathrm{H}_{\mathrm{c}}$ values are widely distributed beyond the PSD field. To examine the effect of the content of magnetite on $\mathrm{J}_{\mathrm{rs}} / \mathrm{J}_{\mathrm{s}}, \mathrm{H}_{\mathrm{c}}$, and $\mathrm{H}_{\mathrm{cr}} / \mathrm{H}_{\mathrm{c}}$, these three parameters were plotted against $J_{s}$ (Fig. 7). While $J_{r s} / J_{s}$ is not correlated to $J_{s}, H_{c}$ increases and hence $\mathrm{H}_{\mathrm{cr}} / \mathrm{H}_{\mathrm{c}}$ decreases with increasing $\mathrm{J}_{\mathrm{s}}$. Although the influence of paramagnetic material was eliminated for the determination of $\mathrm{J}_{\mathrm{s}}$ and $\mathrm{J}_{\mathrm{rs}}, \mathrm{H}_{\mathrm{c}}$ values are possibly affected by a paramagnetic contribution. A higher paramagnetic contribution results in apparently lower $\mathrm{H}_{\mathrm{c}}$ values. Higher $\mathrm{H}_{\mathrm{cr}} / \mathrm{H}_{\mathrm{c}}$ values could thus be an artifact of the very low content of magnetite.

\section{Remanence Properties}

NRM intensity, low-field susceptibility, and Koenigsberger ratio are given in Table 2 and plotted with depth in Figure 8. Averages of these parameters are presented in Table 3 in comparison with those from Hole 504B.
The diabase sills collected at Site 857 have a very low average NRM intensity $(0.11 \mathrm{~A} / \mathrm{m})$. This average value is more than one order of magnitude lower compared with young oceanic basalts from the basalt section of Hole 504B (Table 3). There is no significant systematic trend in NRM intensity with depth. NRM intensities of most samples range from $10^{-2}$ to $10^{-1} \mathrm{~A} / \mathrm{m}$ except for higher values for the uppermost sills and the sills at about $800 \mathrm{mbsf}$ with higher $\mathrm{J}_{\mathrm{s}}$ values, which are still lower than those of typical young oceanic basalts.

Low-field susceptibility, a reliable measure of the induced magnetization, is due to "ferromagnetic" and paramagnetic phases. Although the grain size of ferromagnetic minerals is an important factor, the susceptibility value reflects mainly the content of ferromagnetic and paramagnetic materials. Susceptibility values from Site 857 show no systematic variation with depth. Again, the uppermost and 800 mbsf sills are exceptions, with higher susceptibility values. The average susceptibility value of 0.0016 SI units is one order of magnitude lower than that of young oceanic basalts. Even compared to the observed values of the transition zone of Hole 504B, which suffered greenschist facies alteration, this average value from Site 857 is significantly lower. Such a low average value and variation with depth is consistent with the measured saturation magnetization. However, the thermomagnetic curves have hyperbolic forms characteristic of paramagnetic materials (Fig. 1B). Thus, similar features in susceptibility and $\mathrm{J}_{\mathrm{5}}$ may arise from the parallel reduction in the content of ferromagnetic and paramagnetic minerals by hydrothermal fluids.

The Koenigsberger ratio is a ratio of the remanent magnetization intensity to the induced magnetization intensity by the present geomagnetic field. Koenigsberger ratio values of less than one indicate that induced magnetization dominates the remanence. Average values of the diabase sills from Site 857 are near unity, indicating that the 


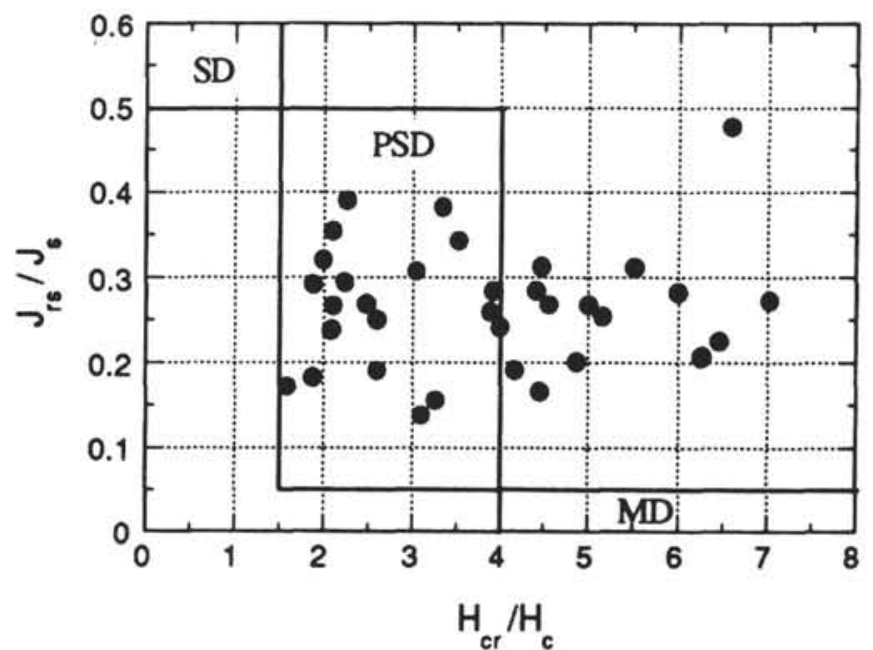

Figure 6. Plot of $\mathrm{J}_{\mathrm{rs}} / \mathrm{J}_{\mathrm{s}}$ vs. $\mathrm{H}_{\mathrm{cr}} / \mathrm{H}_{\mathrm{c}}$ for diabase sills from Site 857. SD, PSD, and MD denote the range of single-domain, pseudo-single-domain, and multidomain grains proposed by Day et al. (1977).

remanent and induced magnetization are nearly equal. Compared with the values from Hole 504B, the value of unity for Site 857 is significantly lower than that of the transition zone as well as the extrusive basalts. The depth variation of the Koenigsberger ratio shows two small highs at 470 and $800 \mathrm{mbsf}$, coinciding with those of $\mathrm{J}_{s}, \mathrm{NRM}$ intensity, and susceptibility.

To estimate the stability of remanent magnetization and magnetic grain size, we performed a modified Lowrie-Fuller test (Johnson et al., 1975) for nine selected samples. Two examples are shown in Figure 9. For most samples, ARM is more stable against AF demagnetization than IRM (Fig. 9A). This behavior is characteristic of single- and pseudo-single-domain grains, and is similar to that for the bimodal type of single-domain and multidomain grains (Dunlop, 1983). Figure 9B illustrates a result from a sample with a high content of magnetic minerals from about $800 \mathrm{mbsf}$. Although ARM is more resistant than IRM, both remanences are much softer than those of the other samples, shown in Figure 9A. This type of behavior is subject to the "transitional" or "mixed" type of Dunlop's (1983) categories, in which the content of single- or pseudo-single-domain grains is lower than the bimodal type. The Lowrie-Fuller test results indicate that samples from Site 857 with a higher content of magnetite contain relatively larger magnetic grains. This observation is consistent with the depth variation of $\mathrm{J}_{\mathrm{s}}, \mathrm{J}_{\mathrm{rs}} / \mathrm{J}_{\mathrm{s}}$ (Fig. 5).

\section{Remanence Direction}

Our samples from Site 857 were not oriented by azimuth but oriented with respect to vertical, allowing the determination of an inclination of remanence direction. We conducted progressive $\mathrm{AF}$ demagnetization of NRM, in order to evaluate the stability of NRM to $\mathrm{AF}$ and hence determine the inclination of the stable component. The direction of the stable component was calculated by principal component analysis from AF demagnetization data (Kirschvink, 1980). For comparison, seven samples were subjected to progressive thermal demagnetization in air to assess the secondary magnetizations.

The AF demagnetization results are presented on orthogonal plots and equal-area projections (Fig. 10). Based on magnetization behaviors during $\mathrm{AF}$ demagnetization, we divided our samples into two categories: (1) univectorial and (2) bivectorial. AF demagnetization of some samples shows that a stable component, showing a linear segment pointing to the origin of an orthogonal plot, is present and a secondary component is negligible (Fig. 10A). The stable components of univectorial samples have positive inclinations with values concordant to the expected value $\left(+66^{\circ}\right)$ from the geocentric axial
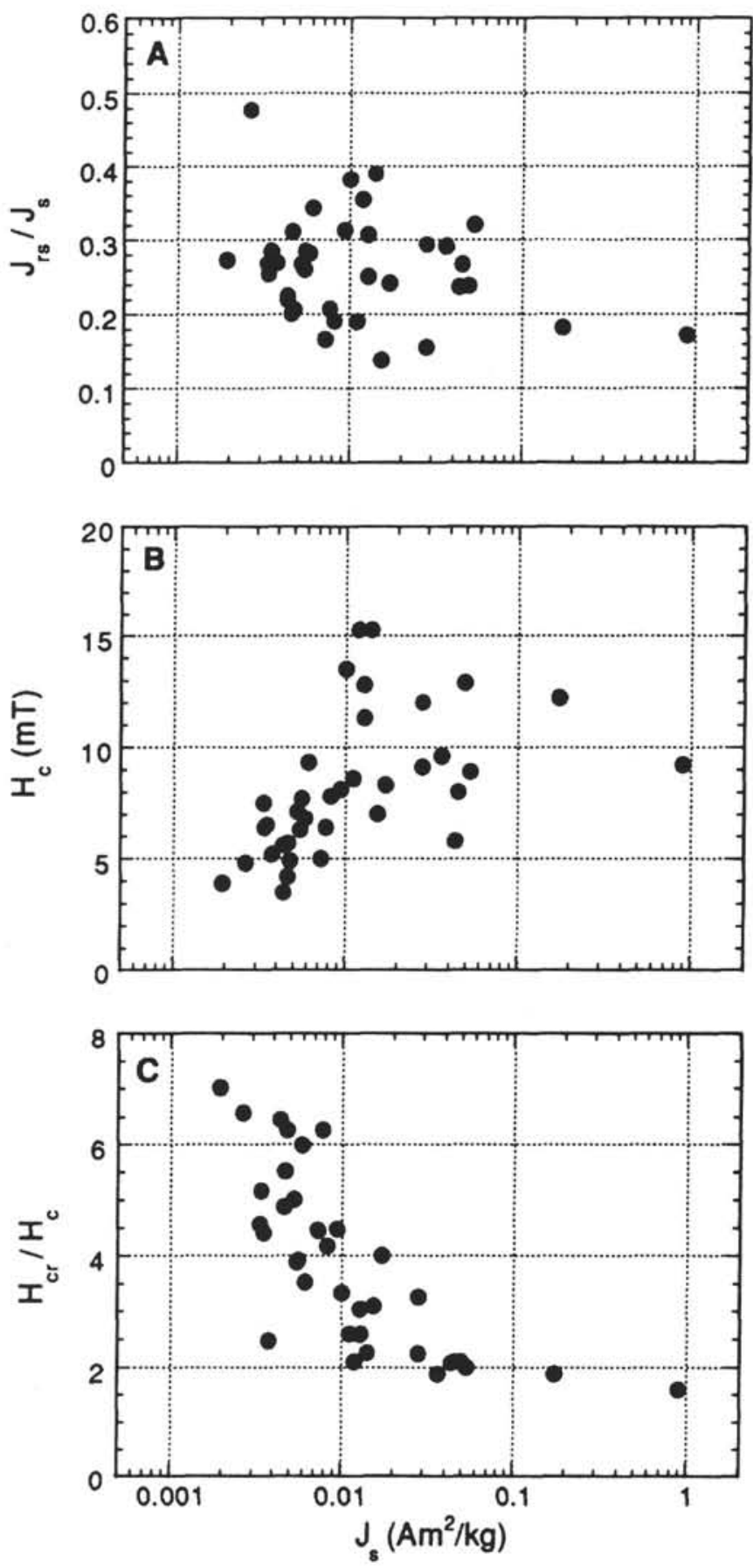

Figure 7. Variations of (A) $\mathrm{J}_{\mathrm{r}} / \mathrm{J}_{\mathrm{s}}$, (B) $\mathrm{H}_{\mathrm{c}}$ and $\left(\right.$ C) $\mathrm{H}_{\mathrm{cr}} / \mathrm{H}_{\mathrm{c}}$ with $\mathrm{J}_{\mathrm{s}}$. Plotted points are limited to the samples with $\mathrm{H}_{\mathrm{cr}}$ values.

dipole field at Site 857 . However, only a small percentage of samples from the upper sills of Hole $857 \mathrm{C}$ satisfy this category. Most samples recovered from Site 857 have bivectorial magnetization. Magnetization of these samples shows gradual changes in direction during AF demagnetization, and the trace on an equal-area projection defines part of a great circle (Fig. 10B). This behavior suggests that the AF coercivity ranges of the lower and higher coercivity components overlap each other. For these samples we could not determine stable inclination values.

Regardless of the AF demagnetization characteristics, both lower and higher coercivity components have reversed and normal polari- 

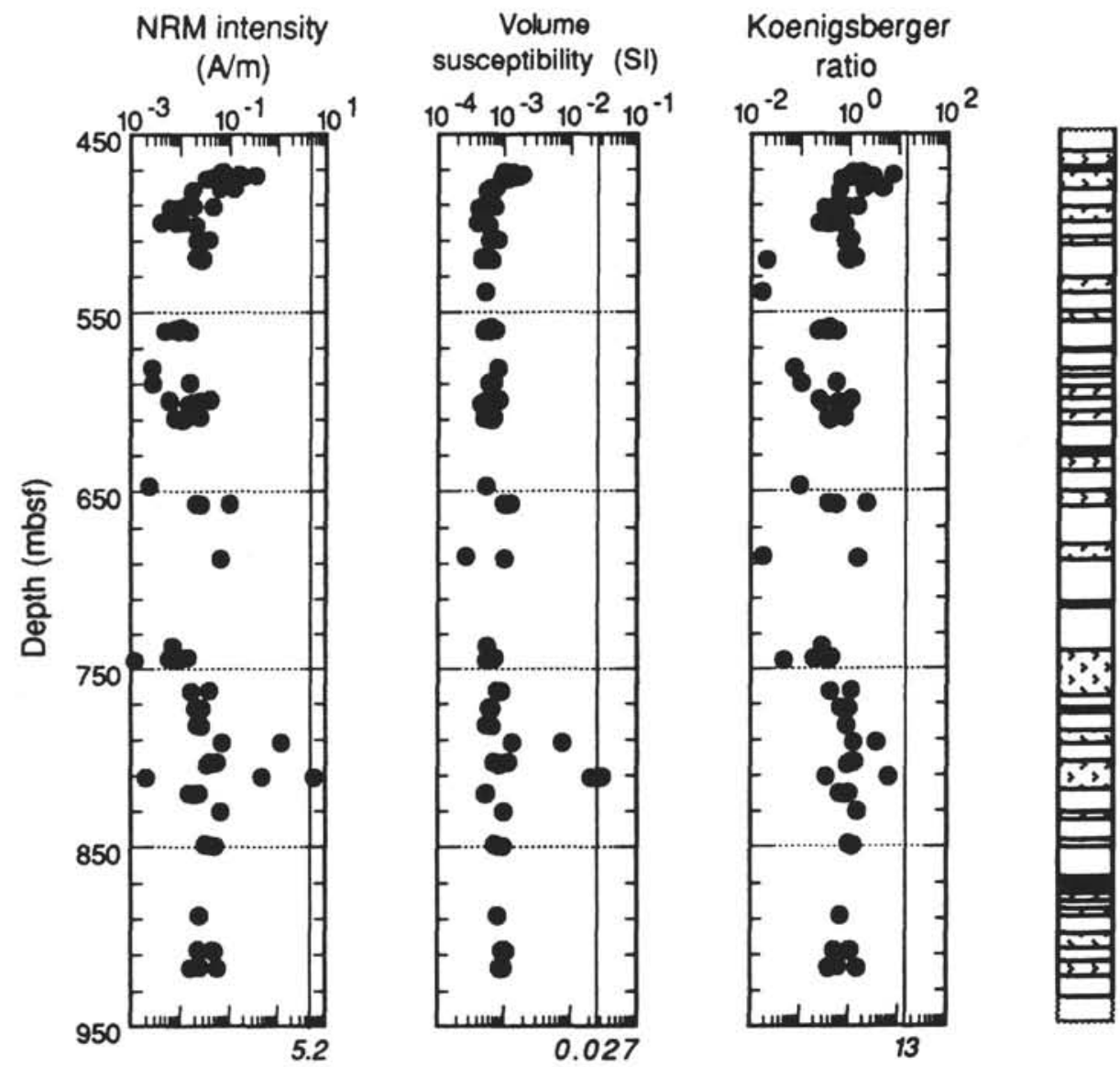

Figure 8. Depth variations of remanence properties from Site 857. Vertical lines represent the average values from Hole 504B basalts (Pariso and Johnson, 1991). Lithology is shown at the right of this figure.

ties, respectively, for all samples with bivectorial magnetization. We interpret the higher coercivity component to be primary magnetization and the lower one to be acquired during the drilling. This is because the lower coercivity component has a steeply inclined direction and is not highly resistant to AF demagnetization, which is characteristic of drilling-induced remanence as previously described (Jackson and Van der Voo, 1985; Özdemir et al., 1988; Audunsson and Levi, 1989). Furthermore, consistently reversed polarity of the lower coercivity component is common to drilling-induced remanence for ODP cores (e.g., Kikawa and Pariso, 1991). Audunsson and Levi (1989) argued that drilling-induced remanence is an isothermal remanence induced by the magnetic field generated from the drill string. However, during coring the rock samples at Site 857 were rapidly cooled from the in-situ temperature $\left(300^{\circ} \mathrm{C}\right)$ by circulating drilling fluids. The low-coercivity magnetization found in samples from Site 857 may be not an isothermal remanence but a partial thermoremanence (e.g., Özdemir et al., 1988).

Thermal demagnetization results are shown in Figure 11A. A low unblocking temperature component with vertically upward direction is removed from room temperature to $400^{\circ} \mathrm{C}$. This maximum unblocking temperature is roughly comparable to the in-situ temperature. These observations support the idea that the secondary magnetization found at Site 857 is probably of partial thermoremanence origin. Between $400^{\circ} \mathrm{C}$ and $500^{\circ} \mathrm{C}$ the demagnetization path is directed to the origin of the orthogonal plot. This component might be of primary origin. This behavior indicates that the unblocking temperature spectra of drilling-induced remanence and primary magnetization do not completely overlap unlike the AF coercivity spectra. Above $500^{\circ} \mathrm{C}$ the magnetization ill behaved and a spurious component was probably acquired. Low-field susceptibility was measured at each step during thermal demagnetization (Fig. 11B). As previously shown in the case of the PThD of composite IRM, susceptibility continuously increases above $400^{\circ} \mathrm{C}$, probably due to oxidation of iron-bearing minerals in air. Although thermal demagnetization is more effective in isolating the secondary drilling-induced remanence, the stable component direction cannot be absolutely isolated.

NRM inclinations prior to AF demagnetization and inclinations of stable components are listed in Table 2 and plotted vs. depth in Figure 12. NRM inclinations are highly scattered and mostly negative, although there are some positive values in the upper interval of Hole $857 \mathrm{C}$ at about $500 \mathrm{mbsf}$. On the other hand, stable inclinations through progressive AF demagnetization show positive values with no exceptions, although the number is very limited. Most samples from Site 857 possess bivectorial magnetizations with overlapping AF coercivity spectra (Fig. 10B). Negatively inclined drilling-induced remanence dominates the NRM, so NRM inclinations are mostly negative. Although stable inclinations could not be obtained from these samples, the higher coercivity components show normal polarities during $\mathrm{AF}$ demagnetization with no exceptions.

\section{DISCUSSION}

\section{Evaluation as a Source of Marine Magnetic Anomalies}

Previous studies of magnetic anomalies over spreading centers (Talwani et al., 1971; Klitgord et al., 1975) and magnetic properties of young oceanic crust (Irving, 1970; Johnson and Atwater, 1977) show that the source of magnetic anomalies over young oceanic crust is predominantly in extrusive basaltic Layer 2A, probably in the upper 0.5-1 km. Recent studies of MAGSAT data call upon long-term acquisition of remanent magnetization to account for the observed 
A

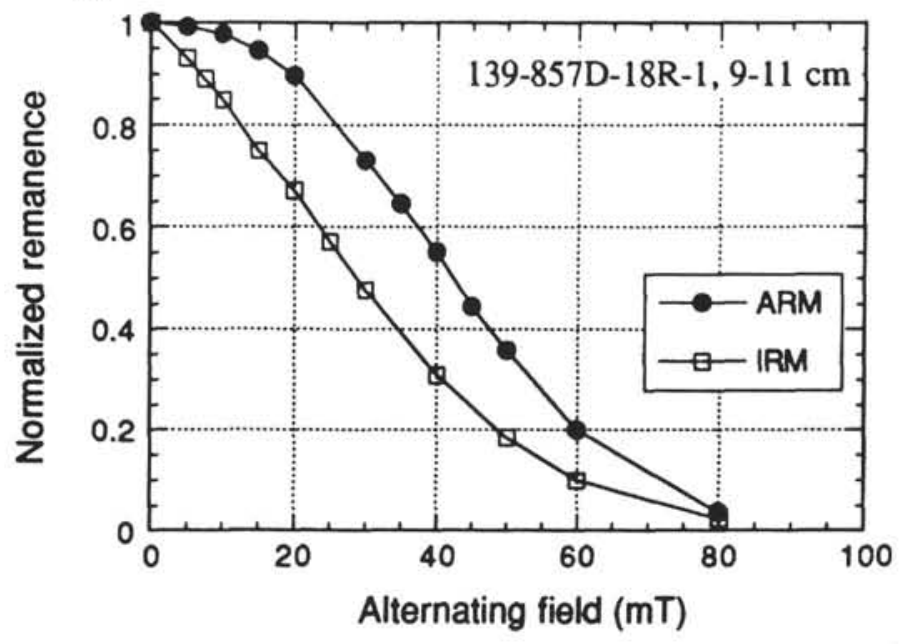

B

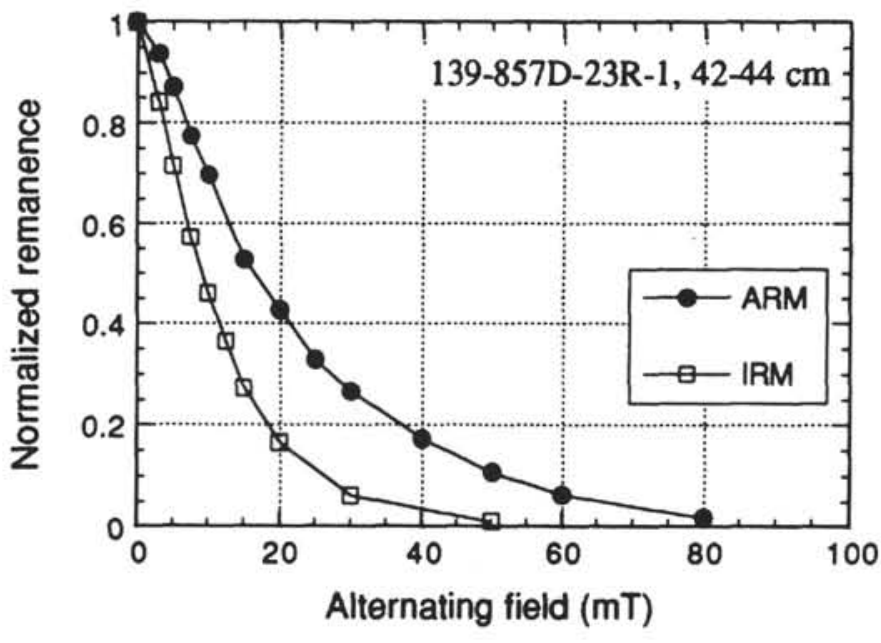

Figure 9. Comparison of normalized AF demagnetization curves of ARM and IRM. A. Single/pseudo-single-domain or bimodal type. Median destructive fields (MDF) of ARM and IRM are 43 and $29 \mathrm{mT}$, respectively. B. "Transitional" or "mixed" type (Dunlop, 1983). MDF of ARM and IRM are 16 and $10 \mathrm{mT}$, respectively. IRM was produced in an external field of $140 \mathrm{mT}$, and ARM was imposed by a $0.05 \mathrm{mT}$ direct field applied parallel to a decaying AF with peak magnitude of $140 \mathrm{mT}$.

long-wavelength anomalies (Raymond and LaBrecque, 1987), and the source of the long-wavelength anomalies is sometimes attributed to the deeper section of the oceanic crust, such as the sheeted dike and the gabbro sections (Arkani-Hamed, 1989; Kikawa and Pariso, 1991; Pariso and Johnson, 1991). However, at Sites 855 and 857 it is not necessary to consider the contributions of the deeper section to the overlying marine magnetic anomalies. Because Middle Valley is a recently active oceanic rift valley, the deeper section does not carry significant remanent magnetization because of its high temperature.

When evaluating the potential of oceanic crustal rocks to contribute to overlying marine magnetic anomalies, we should take into account several rock magnetic properties: the intensity of NRM, the ratio of the remanent magnetization to the induced magnetization (Koenigsberger ratio), the stability of the magnetization with time, and the directional coherence of the magnetization. Basaltic rocks drilled at Site 855 are both mineralogically and magnetically similar to most observed Layer $2 \mathrm{~A}$ basalts. The principal magnetic mineral is titanomaghemite. NRM intensity values $(9.7 \mathrm{~A} / \mathrm{m})$ are high and by far dominate the induced magnetization (Koenigsberger ratio $=19$ ), and the magnetic stability is fairly high $\left(\mathrm{J}_{\mathrm{rs}} / \mathrm{J}_{\mathrm{s}}=0.28, \mathrm{H}_{\mathrm{c}}=9.0 \mathrm{mT}\right)$ to retain its original remanence. These rock magnetic properties indicate a high potential of the basaltic rocks at Site 855 to contribute to marine magnetic anomalies.

In contrast, the diabase sills from Site 857 are characterized by a very low concentration of magnetite. The overall mean value of NRM intensities, even including the intervals with anomalously high NRM intensities, is one order of magnitude lower than that of young oceanic basalts from DSDP/ODP Hole 504B. These low NRM intensities can be attributed to the low concentration of magnetite in the sills at Site 857 , shown by the low saturation magnetization and susceptibility values (Table 3). The average Koenigsberger ratio of unity for the sills of Site 857 suggests that the remanent magnetization is similar to the induced magnetization. To make a significant contribution to the overlying magnetic anomalies, the remanent magnetization of rocks needs to exceed the induced magnetization to some extent. The diabase sills from Site 857 do not satisfy this necessary condition.

On the other hand, the magnetic stability of the sills at Site 857 is fairly high and comparable to that of the basalt section of Hole 504B (Table 3). The sills show relatively high $\mathrm{J}_{\mathrm{rs}} / \mathrm{J}_{\mathrm{s}}(0.28)$ and $\mathrm{H}_{\mathrm{c}}$ values (7.55 mT). We could not determine the median destructive field (MDF) of the NRM because the NRM of most samples has a bivectorial nature caused by the drilling-induced remanence. Instead of NRM, we determined the MDFs of laboratory-induced remanences such as ARM or IRM. These MDF values are mostly greater than 10 $\mathrm{mT}$ (Fig. 9), suggesting that viscous remanent magnetization is insignificant for our samples, and the sills at Site 857 seemingly retain the original remanence.

The observed inclinations of the stable component probably represent the in-situ magnetization direction of the sills from Site 857. We were able to obtain the stable inclinations for only about $30 \%$ of the vertically oriented samples. These samples showed positive stable inclination values, as expected from the geocentric dipole field $\left(+66^{\circ}\right)$. For the other samples, it was impossible to identify stable components; high-coercivity components indicate normal polarities without exception. These results imply that the directions of the in-situ magnetization of the sills at Site 857 are coherent throughout the recovered section and parallel to the average geomagnetic field during the Brunhes normal Chron. This implication fits the observation that the Middle Valley, including Site 857 , is located within the Brunhes-age crust identified from the regional magnetic anomaly pattern (Raff and Mason, 1961).

From the magnetic properties of the diabase sills at Site 857, we can make the following conclusions. Although the sills have stable and normal polarity magnetizations, the remanence intensity is quite low and similar to the induced magnetization intensity. It is unlikely that the sills at Site 857 could make a substantial contribution to marine magnetic anomalies.

On the other hand, the magnetic properties from Site 857 can be explained by intense hydrothermal alteration. The very low saturation magnetization values indicate that the sills contain much less magnetic material than do either Hole 504B or Site 855 basalts. Fairly high magnetic stability, estimated from the large $\mathrm{J}_{\mathrm{rs}} / \mathrm{J}_{s}, \mathrm{H}_{\mathrm{c}}$, and MDF values, suggests a small effective magnetic grain size for magnetite. The severe hydrothermal alteration of magnetic minerals, including extensive iron leaching from the original $\mathrm{Fe}$-Ti oxides, results in the reduction of both the content of magnetic material and effective magnetic grain size. Microscope observations support this mechanism for the Site 857 sills. Fe-Ti phenocrysts in the highly altered sills appear to be almost ghosts, suggesting "granulation" as described by Ade-Hall et al. (1971). During this process, original iron either remains in the magnetite host or is leached from the spinel lattice.

The mechanism of hydrothermal alteration is applicable to the difference in magnetic properties among the sill units at Site 857. The 
A $139-857 \mathrm{C}-64 \mathrm{R}-2,41-43 \mathrm{~cm}$

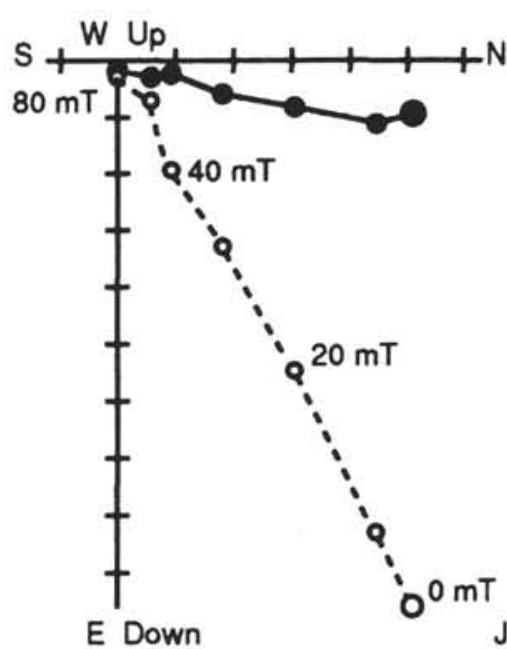

$\mathrm{Jo}=2.72 \mathrm{E}-2 \mathrm{~A} / \mathrm{m}$

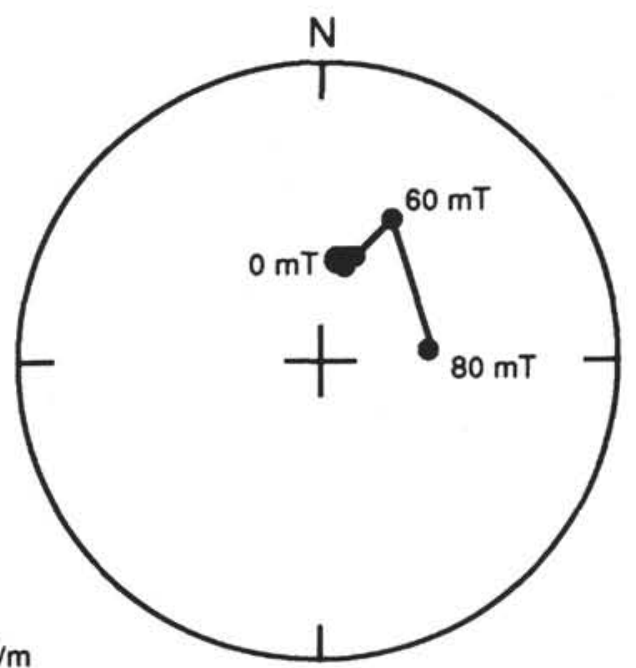

B $139-857 \mathrm{D}-18 \mathrm{R}-1,110-112 \mathrm{~cm}$
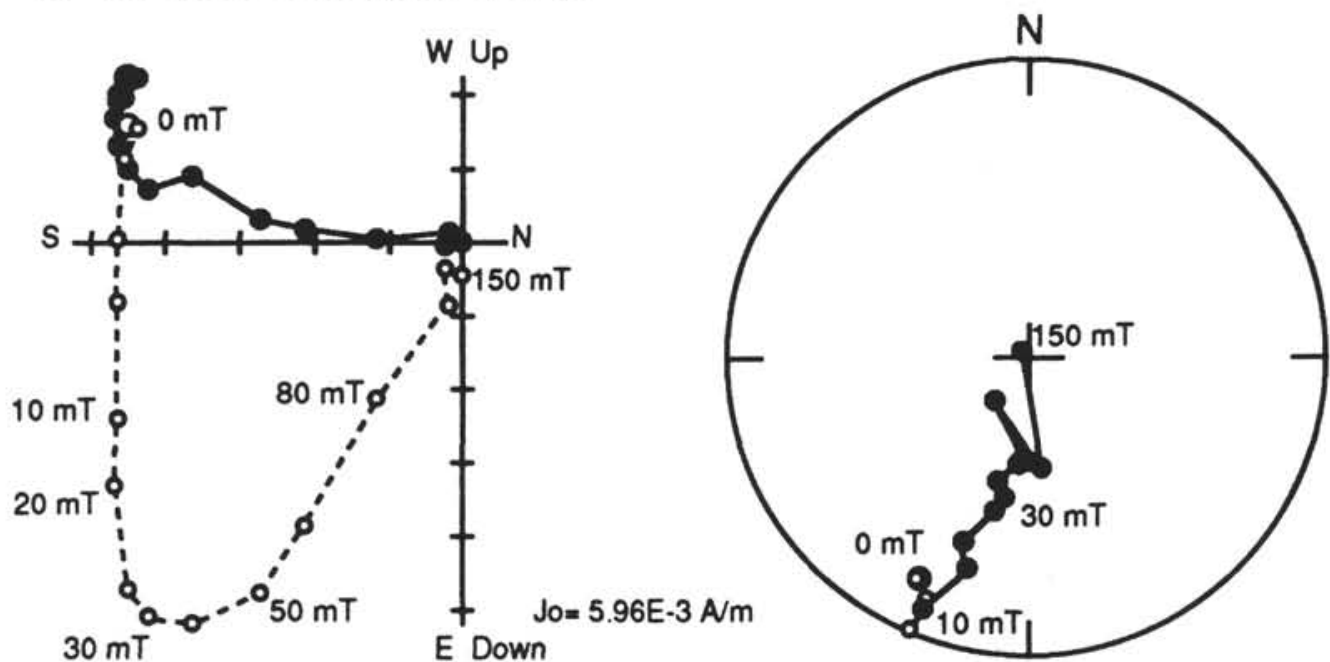

Figure 10. Orthogonal plots and equal-area projections of magnetization behavior during AF demagnetization. A. Univectorial NRM. B. Bivectorial NRM with overlapped AF coercivity spectrum. Open and solid circles on the orthogonal plots represent the projected vector end points of magnetization on vertical and horizontal planes, respectively. Open and solid symbols on equal-area projections show the projected points on the upper and lower hemisphere, respectively. $\mathrm{J}_{0}$ denotes the remanence intensity prior to demagnetization.

sills at about 470 and 800 mbsf have anomalously high values in saturation magnetization, susceptibility, and NRM intensity (Figs. 5 and 8). Petrographic observation confirmed that the low degree of alteration corresponds to these intervals (Davis, Mottl, Fisher, et al., 1992). The local availability of hydrothermal fluids, related to the permeability of rocks, probably controls the different magnetic properties of the individual sills at Site 857 . Lower $\mathrm{J}_{\mathrm{rS}} / \mathrm{J}_{\mathrm{s}}$ values in these intervals suggest that larger magnetic grains remain relatively unaltered in these sills.

\section{Origin of the Subdued Marine Magnetic Anomalies over Middle Valley}

This section summarizes hypothesized mechanisms for subduing magnetic anomalies in sedimented rifts and expected magnetic prop- erties in comparison with the observed magnetic properties from the diabase sills at Site 857 (Table 4).

Elevated temperature above Curie temperatures of magnetic minerals makes them paramagnetic and eliminates the remanent magnetization of host rocks. When the temperature of the rock is lower, but still close to Curie temperatures of the magnetic minerals, the spontaneous magnetization is significantly decreased and hence the remanent magnetization is reduced to a great extent. Site 857 is in an area with an estimated temperature of about $300^{\circ} \mathrm{C}$ at the base of the sediment section (Davis and Villinger, 1992). Here, the igneous crust is sealed by sediment, and high-temperature fluids may reside in a hydrothermal reservoir. A temperature of $222^{\circ} \mathrm{C}$ measured at 476 mbsf during the recovery from the drilling disturbance provides a lower limit of the in-situ temperature of the sills at Site 857 (Davis, Mottl, Fisher, et al., 1992). This temperature exceeds the Curie temperatures of $100^{\circ} \mathrm{C}$ to 
A $139-857 \mathrm{D}-18 \mathrm{R}-2,43-46 \mathrm{~cm}$
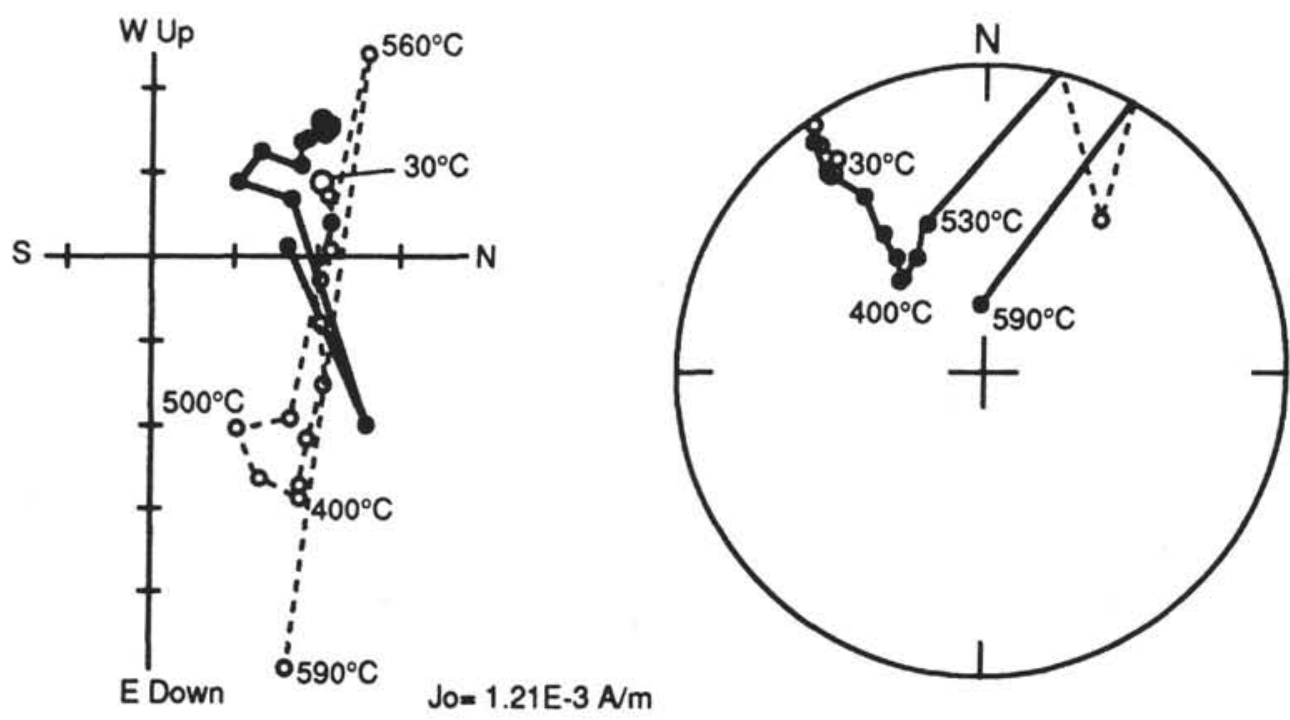

B

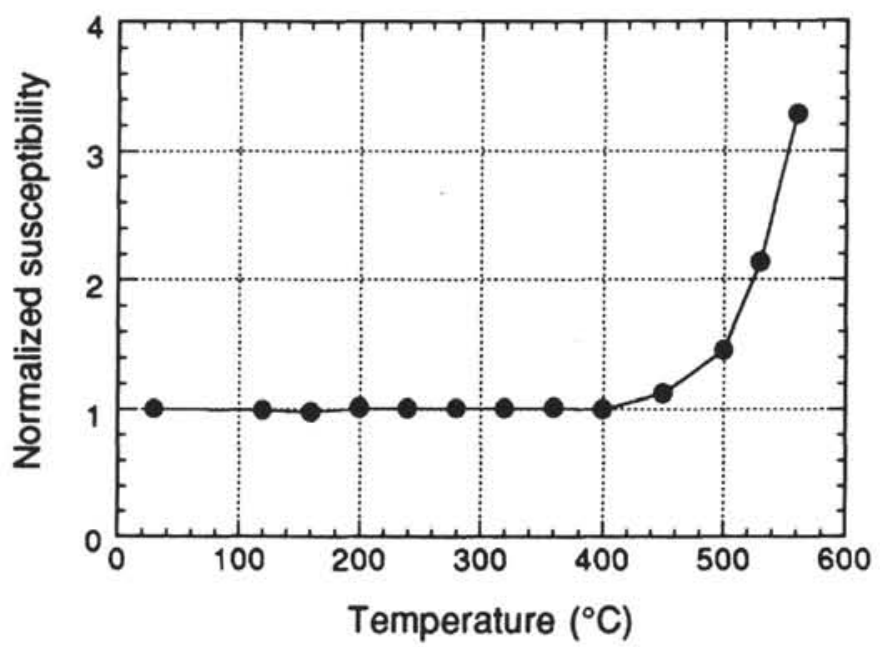

Figure 11. Orthogonal plot and equal-area projection of magnetization behavior (A) and susceptibility variation (B) during progressive thermal demagnetization. Symbols and conventions as in Figure 10.

Table 4. Hypothesized mechanisms for subduing magnetic anomalies in sedimented rifts and the results from Site 857.

\begin{tabular}{llll}
\hline \multicolumn{1}{c}{ Mechanisms } & \multicolumn{1}{c}{ Consequences } & \multicolumn{1}{c}{$\begin{array}{c}\text { Expected } \\
\text { magnetic properties }\end{array}$} & \multicolumn{1}{c}{$\begin{array}{c}\text { Site } 857 \\
\text { magnetic properties }^{\mathrm{a}}\end{array}$} \\
\hline Intrusions & Large grain size & $\begin{array}{l}\text { Low remanence intensity } \\
\text { Low stability }\end{array}$ & $\begin{array}{l}\text { Low remanence intensity } \\
\text { High stability }\end{array}$ \\
Elevated temperature $\left(>300^{\circ} \mathrm{C}\right)$ & Low spontaneous magnetization & $\begin{array}{l}\text { Low remanence intensity } \\
\text { Low remanence intensity } \\
\text { Ligh Curie point }\left(570^{\circ} \mathrm{C}\right)\end{array}$ \\
Hydrothermal leaching & Dissolution of magnetic minerals & $\begin{array}{l}\text { Low remanence intensity } \\
\text { Low concentration remanence intensity } \\
\text { Low concentration }\end{array}$ \\
& & & Low con
\end{tabular}

${ }^{a}$ Relative to those of Hole 504B basalts.

$200^{\circ} \mathrm{C}$ for unoxidized titanomagnetite in typical young oceanic basalts (Johnson and Hall, 1978; Marshall, 1978). Extensive maghemitization of primary titanomagnetite can increase Curie temperatures to as high as $400^{\circ} \mathrm{C}$ (Bleil and Petersen, 1983). If the remanent magnetization at Site 857 is carried by titanomagnetite or titanomaghemite as young oceanic basalts, the remanence would be eliminated or sub- stantially reduced according to the degree of maghemitization at the high-temperature conditions of $300^{\circ} \mathrm{C}$. However, the principal magnetic mineral in the sills at Site 857 is nearly pure magnetite, with Curie temperature of $580^{\circ} \mathrm{C}$. The spontaneous magnetization of pure magnetite at $300^{\circ} \mathrm{C}$ is lowered by about $20 \%$ compared to the roomtemperature value (Panthenet, 1952). Because the magnetite in the 


\section{NRM inclination (degrees)}

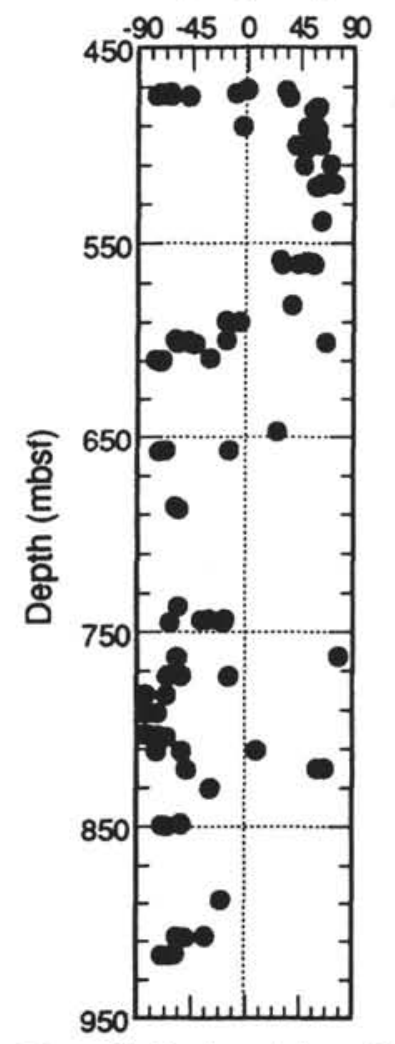

\section{Stable inclination (degrees)}
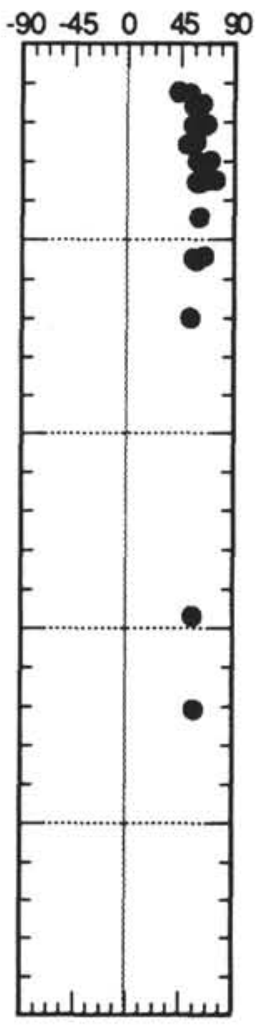

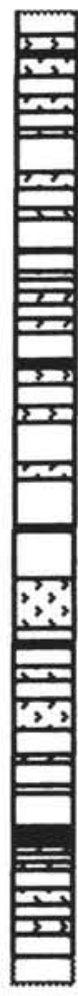

Figure 12. Depth variation of NRM and stable inclination from Site 857. Lithology is shown at the right of this figure.

sills is in the pseudo-single-domain range, the in-situ intensity of remanent magnetization is lowered by roughly the same degree as the spontaneous magnetization (McClelland and Sugiura, 1987). Although elevated temperature in the sills might be partly responsible for the subdued marine magnetic anomalies over Middle Valley, this mechanism alone seems insufficient to explain highly suppressed magnetic anomalies.

Magma crystalizing under sediment will not form extrusive basalts but will cool more slowly to produce intrusive rocks that have a grain size larger than that of extrusive basalts of similar composition. Larger grain-size magnetic minerals generally correspond to lower specific remanence intensities and lower stabilities (O'Reilly, 1984). Therefore, the intrusive rocks formed beneath a thick sediment cover cannot make a significant contribution to marine magnetic anomalies. A similar explanation, involving salt as a host rock rather than sediment, was proposed for the northern Red Sea (Girler, 1985). However, Levi and Riddihough (1986) argued that intrusive rocks may have high remanence intensities and stabilities similar to the extrusive pillow basalts based on the data from drilled cores at DSDP Holes 417D and 418A (Levi, 1979). On the other hand, the sheeted dike complex of Hole 504B shows a somewhat lower intensity but similar stability to the overlying basalt section (Table 3) (Pariso and Johnson, 1991), and submarine diabase rocks drilled during DSDP Legs 51 and 52 were reported with a low NRM intensity and a large viscous component of remanence (Smith, 1987). Such a difference in remanence intensity and stability among submarine intrusive rocks probably depend on the microstructure of $\mathrm{Fe}$-Ti oxides, and hence the cooling rate. In any case, primary titanomagnetite would need to remain large grain-sized and homogeneous following formation in order to explain the subdued marine magnetic anomalies according to this mechanism. However, as previously described, Fe-Ti oxide phenocrysts are mostly ghosts in the samples from Site 857 , and the magnetic properties also indicate the small effective grain size of the magnetic minerals. This mechanism by intrusion does not seem to be applicable to the case of Middle Valley.

We suggest that pervasive hydrothermal alteration of oceanic crust at this sedimented rift offers the most efficient mechanism for suppressing marine magnetic anomalies. Several authors advocated that hydrothermal alteration of submarine basalts would reduce or eliminate marine magnetic anomalies (Luyendyk and Melson, 1967; Opdyke and Hekinian, 1967). Some hydrothermal vent fields are characterized by lower marine magnetic anomalies than expected (Rona, 1978), and are related to low magnetization as shown by the direct measurements of rock magnetics (Wooldridge et al., 1990) and magnetic modeling (Wooldridge et al., 1992). In sedimented rifts such as Middle Valley, impermeable sediment cover limits the recharge and discharge of hydrothermal fluids and thermally insulates the underlying igneous rocks (Davis and Villinger, 1992). More pervasive hydrothermal alteration of igneous rocks will occur beneath sedimented rifts and will lead to the widespread reduction of remanence intensity and magnetic anomalies. Our samples from the sills at Site 857 provide good evidence supporting this hypothesis. These sills have suffered intense hydrothermal alteration and formed epidote, chlorite, and pyrite (Davis, Mottl, Fisher, et al., 1992). The original Fe-Ti oxides are extensively altered and granulated into magnetite and Ti-bearing phases. Part of the iron in the original Fe-Ti oxides may remain in magnetite but most of the iron was leached from the spinel lattice by hydrothermal fluids. Consequently, the amount of magnetic materials is dramatically reduced and the remanent intensity is significantly lowered. Other examples of low remanent magnetization accompanying pervasive hydrothermal alteration exist. In the transition zone at Hole 504B, the original titanomagnetite grains are partially or completely replaced by sphene (Alt et al., 1986) and the magnetization is extremely low compared with that of the overlying basalt (Table 3 ). The replacement of titanomagnetite by anatase pseudomorphs and a corresponding decrease in saturation magnetization below a 2- to $3.1-\mathrm{km}$ crustal section in Iceland is consistent with the iron leaching of hydrothermal fluids (Hall, 1985). The suppressed marine magnetic anomalies over the Middle Valley are responsible for the magnetization low induced by hydrothermal alteration of the igneous rocks beneath the thick sediment cover.

Why are negative, rather than the expected positive, magnetic anomalies observed over Middle Valley? Although Middle Valley is underlain by rocks with an extremely low magnetization, the southern area of Middle Valley is formed by positively magnetized normal oceanic crust (Davis and Lister, 1977). Much as negative anomalies are observed to the north side of positively magnetized seamounts, the negative crustal magnetic field present in the area of Middle Valley is probably due to an edge effect. In addition to the elimination of the expected positive crustal field by intense hydrothermal alteration, the positively magnetized crust situated in the south produces the negative anomalies over Middle Valley.

The proposed mechanism of hydrothermal alteration for subdued magnetic anomalies has the following implications. Igneous rocks formed at sedimented rifts have a very low content of magnetic minerals due to hydrothermal alteration. Hydrothermal leaching is an irreversible process leading to a reduction of magnetization, which is different from the reversible effect of elevated temperatures alone. Thus, the suppressed marine magnetic anomalies over active rifts result in the absence of a lineated magnetic anomaly pattern after seafloor spreading. Some magnetic smooth zones such as the Gulf of Aden, the northern Red Sea, and the northwest Atlantic Ocean are probably originated in sedimented spreading centers like Middle Valley. In general, oceans and marginal seas at the initial stages of rifting may often lack lineated marine magnetic anomalies. 


\section{CONCLUSIONS}

This study of the rock magnetic properties from Sites 855 and 857 in Middle Valley of the northern Juan de Fuca Ridge revealed the following.

1. The magnetic properties of extrusive basalts recovered from Site 855 , which is located at the eastern boundary of Middle Valley, are similar to those of typical young oceanic basalts. These basaltic rocks can be the source of marine magnetic anomalies. In contrast, the diabase sills recovered from Site 857, situated well within Middle Valley, do not contribute to the overlying magnetic anomalies. The NRM intensities at Site 857 are about two orders of magnitude lower than those of typical young oceanic basalts. The Koenigsberger ratios are near unity, indicating that the remanent magnetization is comparable with the induced magnetization. These contrasting rock magnetic properties between Sites 855 and 857 are concordant with the observed marine magnetic anomalies; the expected positive marine magnetic anomalies disappear locally along the axis of the Middle Valley.

2. Magnetic properties at Site 857 are extensively influenced by pervasive hydrothermal alteration. Hydrothermal fluids intensively leached iron from original Fe-Ti oxides, which resulted in the granulation of magnetite and Ti-bearing phases. As seen from the very low saturation magnetization and susceptibility values, the content of magnetic materials was dramatically reduced and hence the NRM intensity was considerably lowered. High values of $\mathrm{J}_{\mathrm{rs}} / \mathrm{J}_{\mathrm{s}}, \mathrm{H}_{\mathrm{c}}$, and MDF reflect the small grain size of the alteration product of magnetite.

3. We have provided clear constraints on how a thick sediment blanket can prohibit the production of magnetic anomalies. Middle Valley is a typical example of a sediment-covered active rift valley lacking the expected positive marine magnetic anomaly. In sedimented rifts, a relatively impermeable sediment cover limits the recharge and discharge of hydrothermal fluids and leads to pervasive hydrothermal alteration of the underlying igneous rocks. Consequently the amount of magnetic materials is dramatically reduced and NRM intensity is significantly lowered. The suppressed marine magnetic anomaly over the Middle Valley is caused by the magnetization low induced by hydrothermal alteration of the igneous rocks beneath a thick sediment cover. This mechanism may also be applicable to the initial rifting stages of many oceans or marginal seas.

\section{ACKNOWLEDGMENTS}

We would like to thank M. Funaki for the use of his vibrating sample magnetometer at National Institute of Polar Research in Tokyo. We appreciate the careful review and helpful comments of the manuscript by M. Torii. Valuable suggestions and criticism given by John W. Geissman and an anonymous reviewer improved the manuscript. This research was supported by a Fellowship of the Japan Society for the Promotion of Science for Japanese Junior Scientists to K.F. and a Grant-in-aid for scientific research of Ministry of Education of Japan (No. 04640702).

\section{REFERENCES ${ }^{*}$}

Ade-Hall, J.M., Palmer, H.C., and Hubbard, T.P., 1971. The magnetic and opaque petrological response of basalts to regional hydrothermal alteration. Geophys. J. R. Astron. Soc., 24:137-174.

Alt, J.C., Honnorez, J., Laverne, C., and Emmermann, R., 1986. Hydrothermal alteration of a $1 \mathrm{~km}$ section through the upper oceanic crust, Deep Sea Drilling Project Hole 504B: mineralogy, chemistry, and evolution of seawater-basalt interactions. J. Geophys. Res., 91:10309-10335.

\footnotetext{
Abbreviations for names of organizations and publications in ODP reference lists follow the style given in Chemical Abstracts Service Source Index (published by American Chemical Society)
}

Arkani-Hamed, J., 1989. Thermoviscous remanent magnetization of oceanic lithosphere inferred from its thermal evolution. J. Geophys. Res., 94:1742117436.

Audunsson, H., and Levi, S., 1989. Drilling-induced remanent magnetization in basalt drill cores. Geophys. J., 98:613-622.

Barr, S.M., and Chase, R.L., 1974. Geology of the northern end of Juan de Fuca Ridge and sea floor spreading. Can. J. Earth Sci., 11:1384-1406.

Bleil, U., and Petersen, N., 1983. Variations in magnetization intensity and low-temperature titanomagnetite oxidation of ocean floor basalts. Nature, 301:384-388.

Channell, J.E.T., and Hawthorne, T., 1990. Progressive dissolution of titanomagnetites at ODP Site 653 (Tyrrhenian Sea). Earth Planet. Sci. Lett., 96:469-480.

Curray, J.R., and Moore, D.G., 1982. Introduction to the Guaymas Basin and hydrothermal symposium. In Curray, J.R., Moore, D.G., et al., Init. Repts. DSDP, 64: Washington (U.S. Govt. Printing Office), 1119-1121.

Davis, E.E., and Lister, C.R.B., 1977. Tectonic structures on the Juan de Fuca Ridge. Geol. Soc. Am. Bull., 88:346-363.

Davis, E.E., Mottl, M.J., Fisher, A.T., et al., 1992. Proc. ODP, Init. Repts., 139: College Station, TX (Ocean Drilling Program).

Davis, E.E., and Riddihough, R.P., 1982. The Winona Basin: structure and tectonics. Can. J. Earth Sci., 19:767-788.

Davis, E.E., and Villinger, H., 1992. Tectonic and thermal structure of the Middle Valley sedimented rift, northern Juan de Fuca Ridge. In Davis, E.E., Mottl, M.J., Fisher, A.T., et al., Proc. ODP, Init. Repts., 139: College Station, TX (Ocean Drilling Program), 9-41.

Day, R., Fuller, M., and Schmidt, V.A., 1977. Hysteresis properties of titanomagnetites: grain-size and compositional dependence. Phys. Earth Planet. Inter., 13:260-267.

Dunlop, D.J., 1983. Determination of domain structure in igneous rocks by alternating field and other methods. Earth. Planet. Sci. Lett., 63:353-367.

Girler, R.W., 1985. Problems conceming the evolution of oceanic lithosphere in the northern Red Sea. Tectonophysics, 116:109-122.

Hall, J.M., 1985. The Iceland research drilling project crustal section: variation of magnetic properties with depth in Icelandic-type oceanic crust. Can. J. Earth Sci., 22:85-101.

Irving, E., 1970. The Mid-Atlantic Ridge at $45^{\circ} \mathrm{N}$. XIV. Oxidation and magnetic properties of basalt; review and discussion. Can. J. Earth Sci., 7:1528-1538.

Jackson, M., and Van der Voo, R., 1985. Drilling-induced remanence in carbonate rocks: occurrence, stability and grain-size dependance. Geophys. J. R. Astron. Soc., 81:75-87.

Johnson, H.P., and Atwater, T., 1977. Magnetic study of basalts from the Mid-Atlantic Ridge, lat. $37^{\circ}$ N. Geol. Soc. Am. Bull., 88:637-647.

Johnson, H.P., and Hall, J.M., 1978. A detailed rock magnetic and opaque mineralogy study of the basalts from the Nasca Plate. Geophys. J. R. Astron. Soc., 52:45-64.

Johnson, H.P., Lowrie, W., and Kent, D.V., 1975. Stability of anhysteretic remanent magnetization in fine and coarse magnetite and maghemite particles. Geophys. J. R. Astron. Soc., 41:1-10.

Kikawa, E., and Pariso, J.E., 1991. Magnetic properties of gabbros from Hole 735B, Southwest Indian Ridge. In Von Herzen, R.P., Robinson, P.T., et al., Proc. ODP, Sci. Results, 118: College Station, TX (Ocean Drilling Program), 285-308.

Kirschvink, J.L., 1980. The least-squares line and plane and analysis of palaeomagnetic data. Geophys. J. R. Astron. Soc., 62:699-718.

Klitgord, K.D., Huestis, S.P., Mudie, J.D., and Parker, R.L., 1975. An analysis of near-bottom magnetic anomalies, seafloor spreading and the magnetized layer. Geophys. J. R. Astron. Soc., 43:387-424.

Larson, P.A., Mudie, J.D., and Larson, R.L., 1972. Magnetic anomalies and fracture zone trends in the Gulf of California. Geol. Soc. Am. Bull., 83:3361-3368.

Levi, S., 1979. Paleomagnetism and some magnetic properties of basalts from the Bermuda triangle. In Donnelly, T., Francheteau, J., Bryan, W., Robinson, P., Flower, M., Salisbury, M., et al., Init. Repts. DSDP, 51, 52, 53 (Pt. 2): Washington (U.S. Govt. Printing Office), 1363-1378.

Levi, S., and Riddihough, R., 1986. Why are marine magnetic anomalies suppressed over sedimented spreading centers? Geology, 14:651-654.

Lowrie, W., 1990. Identification of ferromagnetic minerals in a rock by coercivity and unblocking temperature properties. Geophys. Res. Lett., $17: 159-162$.

Luyendyk, B.P., and Melson, W.G., 1967. Magnetic properties and petrology of rocks near the crest of the Mid-Atlantic Ridge. Nature, 215:147-149. 
Marshall, M., 1978. The magnetic properties of some DSDP basalts from the North Pacific and inferences for the Pacific plate tectonics. J. Geophys. Res., 83:289-308.

McClelland, E., and Sugiura, N., 1987. A kinematic model of TRM acquisition in multidomain magnetite. Phys. Earth Planet. Inter., 46:9-23.

Opdyke, N.D., and Hekinian, R., 1967. Magnetic properties of some igneous rocks from the Mid-Atlantic Ridge. J. Geophys. Res., 72:2257-2260.

O'Reilly, W., 1984. Rock and Mineral Magnetism: Glasgow (Blackie).

Özdemir, Ö., Dunlop, D.J., Reid, B., and Hyodo, H., 1988. An early Proterozoic VGP from an oriented drillcore into the Precambrian basement of Southern Alberta. Geophys. J. Int., 95:69-78.

Ozima, M., and Larson, E.E., 1970. Low- and high-temperature oxidization of titanomagnetites in relation to irreversible changes in the magnetic properties of submarine basalts. J. Geophys. Res., 75:1003-1016.

Panthenet, P.R., 1952. Aimantation spontanee des territes. Ann. Phys., 7:710747.

Pariso, J.E., and Johnson, H.P., 1991. Alteration processes at Deep Sea Drilling Project/Ocean Drilling Program Hole 504B at the Costa Rica Rift: implications for magnetization of oceanic crust. J. Geophys. Res., 91:1170311722 .

Raff, A.D., and Mason, R.G., 1961. Magnetic survey off the west coast of North America $40^{\circ} \mathrm{N}$ latitude to $50^{\circ} \mathrm{N}$ latitude. Geol. Soc. Am. Bull. $71: 1267-1270$.

Raymond, C.A., and LaBrecque, J.L., 1987. Magnetization of the oceanic crust: Thermoremanent magnetization or chemical remanent magnetization? J. Geophys. Res., 92:8077-8088.
Rona, P.A., 1978. Magnetic signatures of hydrothermal alteration and volcanogenic mineral deposits in oceanic crust. J. Volcanol. Geotherm. Res. 3:219-225.

Smith, B.M., 1987. Consequences of the maghemitization on the magnetic properties of submarine basalts: synthesis of previous works and results concerning basement rocks from mainly DSDP Legs 51 and 52 . Phys. Earth Planet. Inter., 46:206-226.

Talwani, M., Windisch, C., and Langseth, M., 1971. Reykjanes ridge crest: a detailed geophysical study. J. Geophys. Res., 76:473-517.

Vine, F.J., and Matthews, D.H., 1963. Magnetic anomalies over oceanic ridges. Nature, 199:947-949.

Wooldridge, A.L., Haggerty, S.E., Rona, P.A., and Harrison, C.G.A., 1990 Magnetic properties and opaque mineralogy of rocks from selected seafloor hydrothermal sites at oceanic ridges. J. Geophys. Res., 95:12351-12374.

Wooldridge, A.L., Harrison, C.G.A., Tivey, M.A., Rona, P.A., and Schouten, H., 1992. Magnetic modeling near selected areas of hydrothermal activity on the Mid-Atlantic and Gorda ridges. J. Geophys. Res., 96:10911-10926.

Date of initial receipt: 1 December 1992

Date of acceptance: 28 April 1993

Ms 139SR-242 


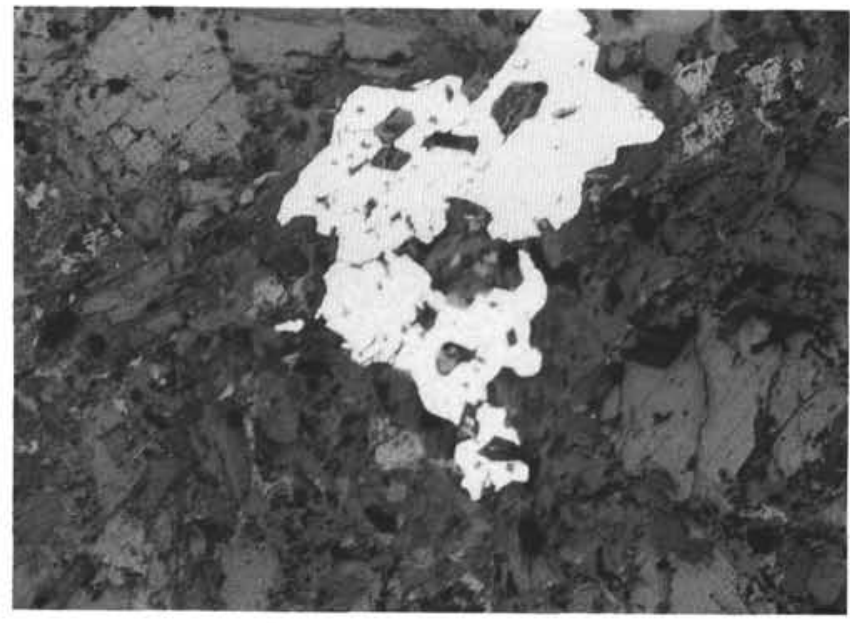

1

$100 \mu \mathrm{m}$

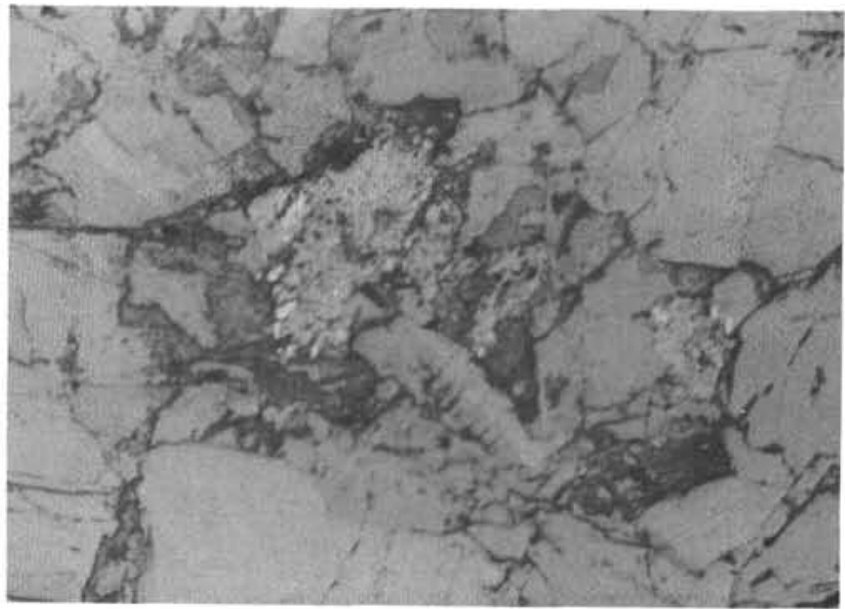

3

$100 \mu \mathrm{m}$

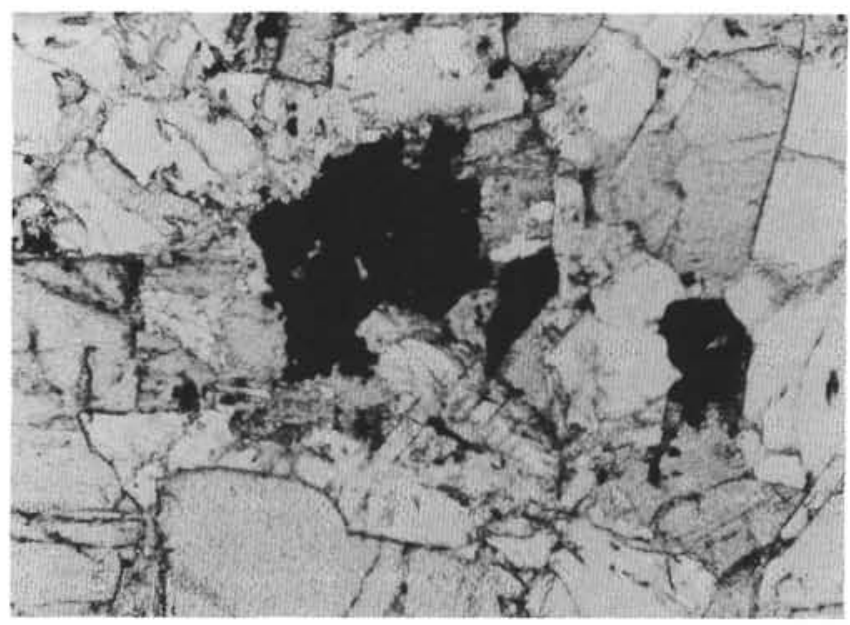

2

$100 \mu \mathrm{m}$

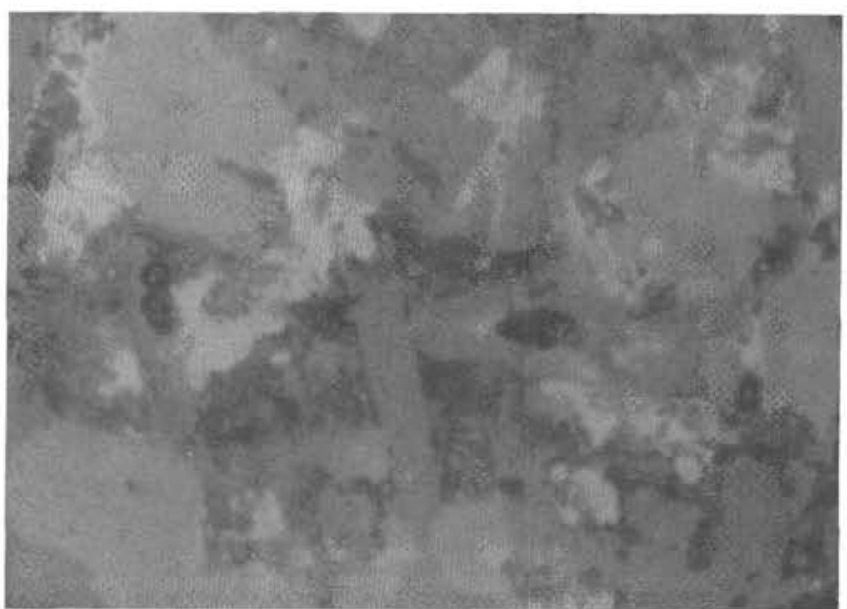

4

$10 \mu \mathrm{m}$

Plate 1. Photographs of opaque minerals from diabase sills at Site 857. 1. Pyrite aggregates. Sample 139-857C-60R-1, 22-24 cm. 2. Ghost of Fe-Ti oxide phenocrysts under transmitted light. Sample 139-857D-18R-1, 9-11 cm. 3. Same sample as Figure 2 under reflected light. 4. Small Fe-Ti oxides. Sample 139-857D-24R-3, 10-12 cm. 